\title{
Hümanizm ve din kavşağında edebiyat
}

\section{Ahmet KAYINTU1}

\begin{abstract}
APA: Kayıntu, A. (2019). Hümanizm ve din kavşağında edebiyat. RumeliDE Dil ve Edebiyat
\end{abstract} Araştırmaları Dergisi, (16), 499-529. DOI: 10.29000/rumelide.619026

\section{$\ddot{O} \mathbf{z}$}

$\mathrm{Bu}$ çalışma, hümanizm, din ve edebiyatın arasındaki ilişkiyi edebiyatı merkeze konumlandırarak ortaya koyma amacına matuftur. Günümüzde tarihten felsefeye ve sosyal bilimlerin diğer alanlarına kadar çok disiplinli bir bakış açısıyla yapılan incelemelere konu olan edebiyatın, bu iki alanın tam ortasında yer aldığı görülmektedir. Bir uygulama örneği olarak edebi incelemelerin günümüzde daha çok seküler niteliğinden ötürü hümanist bir perspektiften ele alınmalarına karşın, tarihsel olarak on dokuzuncu yüzyıla kadar egemen bakış açısının dini karakterde olduğu da bilinmektedir. Günümüzde seküler hümanizmin daha çok gündemde olduğu, bir gerçeğe tekabül ediyor olsa da, olumsuz çağrışımlarından ötürü daha fazla dışlamalara maruz bırakılan dini bakış açılarının toplu olmaktan çok bireysel bir ilgi nesnesi olarak kaldığı ve akademide özellikle her hangi bir şekilde dini veya dini olduğu izlenimi uyandıran bir bakış açısının kasıtlı olarak gözlerden kaçırıldığı da bir gerçektir. Dolayısıyla edebiyatın ve onun hikaye, roman, biyografi gibi alt türlerini nesnel bir şekilde anlamak ve incelemek için onun sadece bir bakış açısının ürünü olmadığı, dahası olmak zorunda olmadığını idrak etmeye gereksinim duyarız. Çünkü edebiyat her şeyden önce insanlardan meydan gelen bir toplumun kültürel dünyasının muhtemelen en iyi yansımasını bulduğu bir alandır. İnsanı ve kültürünü anlama çabası edebiyatın, dinin dışında bir anlam dünyasına sahip olabileceği ne denli geçerli bir önerme ise, aynı şekilde dini bir alanın varlığının ifadesi olarak incelemeye konu olabilmesi de o denli kabul edilebilir. Hümanizm, din ve edebiyat üçlüsünün arasındaki ilişkinin ele alındı̆̆ı bu çalışma iki ana bölüm ve sonuç kısımlarından oluşmaktadır. Birinci bölümde, konunun alt yapısı verilmektedir ve ona ilişkin kuramsal tartışmaların yer almaktadır. İkinci bölümde ise bu ilişkilerin en iyi ifadesini ve uygulamasını bulduğu George Eliot'ın Middlemarch ve Silas Marner adlı romanlarının ayrıntılı tahlilleri yer almaktadır.

Anahtar kelimeler: Hümanizm, edebiyat, din, sekülerizm.

\section{Literature at the crossroad of humanism and religion}

\begin{abstract}
This study aims to reveal the relationship between humanism, religion and literature by positioning literature in the center. Nowadays, literature, which is subject to examinations made from a multidisciplinary point of view, from history to philosophy and other areas of social sciences, appears to be at the center of these two fields. Although, as an example of practice, literary studies are dealt with from a humanist perspective due to their more secular nature, it is historically known that the dominant perspective until the nineteenth century is of religious character. Today, although secular humanism corresponds to a reality in which it is more on the agenda, it is seen that religious perspectives, which are subjected to more exclusion due to negative connotations, remain as an
\end{abstract}

1 Dr. Öğr. Üyesi, Bingöl Üniversitesi, Fen Edebiyat Fakültesi, İngiliz Dili ve Edebiyatı Bölümü (Bingöl, Türkiye), akayintu@bingol.edu.tr, ORCID ID: 0000000165390028 [Makale kaylt tarihi: 23.04.2019-kabul tarihi: 17.09.2019; DOI: $10.29000 /$ rumelide.619026] 


\begin{abstract}
individual object of attention rather than social, and that the view of the academy is particularly religious or religious. it is a fact that it has been deliberately abducted from the eyes. Therefore, we need to realize that literature and its objective to understand and study the sub-genres such as story, novel and biography does not have to be more than just a point of view. Because literature is first and foremost an area where people from the cultural world is probably the best reflection of the cultural world. An attempt to understand human and culture can be accepted as such a valid proposition that literature may have a world of meaning other than religion, and that it can be examined as an expression of the existence of a religious space. This study, which deals with the relationship between humanism, religion and literature, consists of two main sections and conclusion parts. In the first part, the theoretical background of the subject and relevant discussions are given. In the second part, detailed analysis of the novels of Middlemarch and Silas Marner by George in which the best expression and application of these relations are found.
\end{abstract}

Keywords: Humanism, literature, religion, secularism.

Hümanizm, insanı ve insanın mutluluğunu odak noktası olarak belirleyen ve aşkın, metafizik ve doğaüstü konularda kuşkucu olan etik bir geleneğin modern anlamdaki ifadesidir. Tanrı yerine insanı odak referans olarak kabul eder. Rönesans ile birlikte hümanizm, dönemin bilim anlayışını içine alarak hakikati araştırma yolunda ve toplumun refahı için dogmatizm ve sabit fikir yerine, esnek bir fikir yapısını benimser ve insanın mutluluğunu amaç edinir. Hümanizm iki temel anlamıyla öne çıkmıştır: Birinci anlamda tarihsel olarak Avrupa Rönesans'nda klasik öğrenimin canlanmasına ve bu canlanmanın tutuşturduğu düşünce geleneğini ifade eder. İkinci anlamı, daha çağdaş bir zihinsel tutuma işaret eder. Bu ikinci anlamda, on dokuzuncu yüzyıl boyunca, uygulayıcıları "hümanistler" olarak da adlandırılan "hümanizm" in içeriği, sistematik olmaktan uzak olup kelime, genellikle genetik olarak dine inanmayan, teist olmayan veya Hristiyan olmayan bir hayata karşı bir dizi tutuma atıfta bulunularak kullanılmıştır. Terim çoğunlukla olumlu anlamda kullanılmış olmakla birlikte zaman zaman da olumsuz çağrışımlara sahip bir ifade olarak kullanılagelmiştir. Akademide, hala eski ve yerleşik anlamını korumasına karşın hümanizm, yirminci yüzyılda insan hayatına ve tecrübesine önem ve öncelik veren, buna karşın Tanrı, aşkınlık, din, teizm, vahiy ilahi müdahale ve inayet gibi olguları spekülatif addederek reddeden seküler bir düşünce biçimi olarak öne çıtı.

Hümanizm doğası gereği, kuşkucu ve seküler bir karakterdedir, insanın kapasitesinin sınırlı olduğunu kabul eder, fakat özgür iradeye ve bunun bir sonucu olarak insanın ahlaki seçimine önem verir. Hümanist anlayışa göre, dünya esasında kendi başına her hangi bir değerden bağımsız olup bu durumun, daha doğru bir ifadeyle, bu dengenin bozulması anlamına gelir ki bu da irrasyonalite ile nitelendirilir. Bir başka ifadeyle, dünyanın bu dengeli hali hakikate daha yakın, rasyonel olup ilahi bir müdahale irrasyonel olarak anılacaktır. Bundan dolayı hümanizm, ontoloji ya da epistemoloji olmaktan çok değerlerle ilgili bir kavramdır. Hümanizmin bilimden ayrıldığı önemli noktalardan biri de şudur: Bilim, belirli somut nesneleri sayı cinsinden ifade edebilirse de değeri ölçme niteliğinden yoksundur. Kaynağını dünyevilikten alan hümanist bir yaklaşımdan hareket eden Thomas Hardy'e göre insanoğlu, dünyanın sonuna kadar yeryüzündeki etkinliği sevgiye, bilimsel bilgiye, özgür iradeye, organik yaşama dayalı bir zeminde ve dengede sürdürmelidir (Hardy, 1922, s. 10). Bu bakımdan Hardy bilimsel bir hümanist sayılabilir. Hümanizm, kaderci anlayışa karşı olup dini ve ilahi olanı reddettiği gibi bilimsel Marksizm gibi ideolojilerin ön gördüğü toplumsal yapılanmaya da karşıdır.

Günümüzde hümanizmin iki önemli yönü bulunmaktadır: Birincisi, bir yanda genellikle çok elit, seçme insanlarla ilişkilendirilen bir tutum ya da pratik olarak hümanizm ile diğer tarafta hümanizmin eleştirel, 
ilerici, daha özgür bir zihin üreten demokratik bir süreç olabildiği ya da olabileceği fikrine katı bir şekilde itiraz eden çizgi arasında var olduğu kabul edilen bağdır. Başka bir deyişle hümanizmin son derece kısıtlayıcı ve zor bir uğraş olduğu düşünülmektedir.

Buradaki argüman "insani bilimlerin seküler tarih, insan emeğinin ürünleri ve insanın düşüncesini ifade etme yeteneğiyle ilgili olduğu” görüşüdür. "İnsani bilimler 'fiziksel ya da biyolojik doğal süreçlerin genel yasalarıyla ya da kolektif toplumsal koşullar veya güçlerle yeterli bir açıklamaya sı̆̆ış̧ırılamaz... Tüm bu şeylerden oluşmaktadır. Bu şeyler de, kısaca, bizim yaygın bir dille 'insani başarılar' demekle kastettiğimiz şeylerdir. Hümanizm insan iradesi ve eyleminin formel başarısıdır (Said, 2004, s. 15). Hümanizm, insana ilişkin tanımları ve tasarrufları aşkın, ilahi bir amaç uğruna feda etmeyi reddeder. Yalnızca iyi kötü ayrımına dayanan bir insan olgusunu aşan hümanizm, insanın sorumluluğunu ve potansiyeline dayanan felsefi bir duruşun ifadesidir. Hümanist ufku genişletme, onun iç görü ve anlayış kazanımlarını arttırma sürecinde, dış çerçeve aktif olarak anlaşılmalı, inşa edilmeli ve yorumlanmalıdır. Hümanizm, egemen ufukları ve sınırları kabullenmemek, tam aksine, onlara meydan okumaktır (Said, 2004, 76). Dine karşı olan hümanizmin, Marksizme de karşı oluşu paradoksal bir durum oluştursa da hümanizm, bir tür determinizm olduğundan dolayı Marksizme karşı çıkar. Marksizm ile ilişkisinin yanı sıra Hümanizmin tarihsel olarak irdelenmesi onun geçirdiği evreleri ve bugününü daha iyi anlamamız açısından bir gerekliliktir.

Ortaçağda Rönesans hümanizmi, önceleri klasik dönem eserlerinin ve düşünürlerinin fikirlerinin yeniden canlandırılması olarak ortaya çısa da, daha sonra seküler bir hümanizme evrilerek Hıristiyan doktrininin etkisinden sıyrılıp seküler hümanizm olarak nitelendirilebilecek bağımsız bir akım olarak gelişimini sürdürür. Bilindiği üzere, genel olarak edebiyatın özelde de Batı edebiyatının temelinde din vardır: Şiir ve drama dini ritüellerde, Avrupa tiyatrosu (Miracle and Mystery plays) ise, konusunu ve kurgusunu bütünüyle Hıristiyanlıktan ve kilisenin yorumlarından alan yaradılıştan kıyamete kadar pek çok olaylara ve kişilere yer veren Kutsal Kitaptan uyarlanmıştır. Ortaçağın iki büyük şairi Langland ve Chaucer, Piers Ploughman ve Troilus and Criseyde eserleri, Hıristiyan dünya görüşünün somutlaştırıldı $\breve{g} ı$ eserlerdir. On altıncı yüzyıl Rönesans hümanizmi Petrarch, Erasmus, Montaigne, More ve Bacon gibi akademisyenlerle özdeşleşmiş ve bugün "beşeri bilimler" olarak adlandırdığımız bir eğitim programını ortaya koymuştur. Rönesans dünyevi değerler noktasında, Marlowe'un Dr. Faustus'u, Milton'ın Kayıp Cennet'i, Shakespeare'in eserleri hala belirli düzeylerde Hiristiyanlığın etkisinde idi. Ancak 1660'larda Restorasyon dönemine gelindiğinde, kısmen dünyevi bir değer olarak hoşgörü düşüncesi yayılmış ve William Orange'ın bir ihtilal sonucunda 1688'de tahta geçmesiyle birlikte, kendi otoritesini ilahi bir hak olarak meşrulaştırmıştır. Dönemin ünlü filozofu Thomas Hobbes, din ve Tanrı fikrine inanmakla birlikte, Tanrı'nın tanımını meçhul bıraktı. Din ise insanların iyileşmek için alıp kullandıkları fakat hastalıklarına bir faydası olmayan bir takım ilaçlar olarak algılandı. Ancak din fikrinin vazgeçilmez bir işlevi, onun bütün olumsuz çağrışımları fazlasıyla katlanılabilir kılmaktaydı. Dryden 1682'de Religio Laici 'laik din' ifadesini kullanırdı. Hümanizm, diğer bir çağrışımı olan Aydınlanma'nın temel öncülleri ile uyumlu bir birliktelik içindedir: Rasyonel, seküler, kritik bilgi arayışının insanın özgürleşmesine ve ilerlemesine yol açabileceği inancı. Aydınlanma hümanizmi, aksine, savunucuları arasında aralarında Voltaire, Diderot, d'Alembert, Turgot, Condorcet, Hume, Rousseau ve Kant'ın öncülüğünde insanlığı daha iyi hale getirmek için batıl inanç ve cehalete karşı aklın gücünü ve üstünlüğünü savunan on sekizinci yüzyll Avrupa felsefesi hareketidir. (Siddiqi, 2005, s. 69.) Bu bakımdan, hümanizm, 'ötekileri' tanımanın başka yollarına duyulan ihtiyaca işaret eder ve bir ülkeden diğer bir ülkeye diğer halkları ve kültürleri inceleme konusu olarak seçer.

Halil İnalcık, Avrupa tarihinin çok önemli bir dönüm noktasını oluşturan bu dönüşümü şöyle özetler: 
Avrupa tarihinde bu derin değişiklik, her şeyden önce tinsel değişikliktir. Bireyselliğin ön plana çıması, insanlığın özgürlüğü, bu değişikliğin derin nedenidir. Artık birey, bütün Ortaçă̆ boyunca kendisini bağlayan otoritelerin zincirini kırmakta, tam bir özgürlük içinde kendi yeteneklerini kullanmak istemektedir. Tanrı’yı kendi hür vicdanı ile bulmaya çalışıyor, kilisenin aracılığını reddediyordu. Bu yeni birey Reform'un yeni büyük dini hareketlerin de etkisiyle evreni hür aklıyla açıklamak, güzellik dünyasını insani varlığının bütün hürriyeti ile duymak istemekte, skolastiği yıkmaktadır. Modern bilim ve sanatın doğmasına yavaş yavaş zemin hazırlanmaktadır. (İnalcık, 2013, S. 4)

Hümanizm, daha ileri aşamaları geride bırakarak, ruhban sınıfının kiliseye nüfuz ederek kişisel ve kurumsal çıkar sağlamaya alet ettikleri dünyevi bir din haline gelecekti. Ancak daha çok günümüze özgü bir durum olarak algılansa da, Viktorya döneminde de hümanizm ile din arasındaki ilişkinin niteliği, kafası karışık kitlelerin de zihnini kurcalayan bir konuydu. Giderek gündemi daha fazla meşgul eden ve tartışmalarda yer bulan bu konu, yazılı ve sözlü iletişim ortamlarında, gazete, dergi ve kitaplarda etkisi artarak kendisine yer bulmaya başladı.

Yirminci yüzyıla gelindiğinde özellikle ikinci yarısında, 1950'li ve 1960’lı yıllarda hümanist eğitim almış araştırmacılar ve bilim adamlarından oluşan kuşağın gözünde, arka planda kalarak güvende olmayı sürdürdüyse de, akademik söylemde ve kamuoyundaki tartışmalarda hümanizm üzerine pek fazla araştırmalara konu olmamıştır. Soğuk savaşın sona erişi, 1980'li ve 1990'lı yılların kültür savaşlarının ayna tuttuğu başka değişikliklerle hümanizmin ana dalları ile sosyal bilimlerin tarih, feminizm, azınlık hakları ve diğer marjinalleşmiş ve muhalif kesimlerinde, dünyanın her köşesinden yükselen etkileyici çokluktaki muhalif seslerin birbirinin ardından sahnede boy gösterişi, savaş-karşıtı ve ayrımcılık karşıtı mücadelelerle çakışmıştı. Hepsi birlikte düşünüldüğünde, bunlar, yirmi birinci yüzyılın başında bugün sahip olduğumuz hümanist perspektifte meydana gelen değişime katkıda bulunuyordu. Edward Said'e göre, örneğin yeni bir hümanist alan olarak Afrika- Amerika çalışmaları, klasik Avrupa-merkezli hümanist düşüncenin basmakalıp hatta belki de ikiyüzlü nitelikli evrenselciliğini tartışma açarak kendisini çağımızın Amerikan hümanizminin önemli bileşeni olarak öne sürme iddiasını gündeme getirmekte idi. Ve bu değişim Afrikalı Amerikalıların, kadınların ve dezavantajlı ve marjinalleşmiş grupların tarihsel deneyimleri olmadan uzun süre kendisini idare eden hümanizm nosyonunun oldukça iyi düzenlenmiş ve özetlenmiş, daha doğrusu bütün toplumu temsil ettiği düşünülen oysa gerçekte toplumun büyük kesimlerini kapsamayan küçük bir grupla kısıtlanmış işlerlikli bir ulusal kimlik nosyonunun, iyice kuvvetlendiğini açığa çıkarmaktaydı (Said, 2004, ss. 45-46).

Günümüzde hümanizm, artık yeni bir sıfat kazanarak etkinlik alanını daha fazla genişletmiş durumdadır. Artık seküler hümanizmden söz edilebildiği gibi Hıristiyan hümanizminden de söz etmek olanaklı hale gelmiş gibidir. Bu kavram, tutarlı bir dini ve dünyevi görüşü tanımlayan, birbirine bağlı ve birbiriyle ilişkili belirli inanç ve değerleri tanımlar ve birçok insan, tüm dünyada ve binlerce yıldır bu inançlara ve değerlere sahip insanların ünvanı olmaktadır. Bu inançlar ve değerler bir dogmayı oluşturmaz, çünkü temelleri sorgulamaya açıktır. Ancak tarih boyunca, değerinin kaynağını insanın ve insanlığın dışında bulan ve doğaüstü güçleri ve ilkeleri ortaya koyan inanç sistemlerine kalıcı bir alternatif olarak birleşirler. Bu yinelemeye rağmen, nesiller boyunca bu fikirlere açlk bir şekilde teslim olma anlamında bir gelenek oluşturmazlar - hümanizm insan toplumlarında zaman ve mekânda birbirinden oldukça ayrı şekillerde ortaya çıkar ve hümanizmi oluşturan temel fikirler, Çin ve Hindistan'da antik çağlardan eski Akdeniz ve modern Batıda olduğu gibi ayırt edilebilir. (Copson, 2015, s. 5)

Hümanizm kabuğuna çekilip geride durmayla ve dışlamayla ilgili bir şey değildir. Dahası, hümanizm, diğer tercümanlarla ve diğer toplumlarla ve dönemlerle bir topluluk duygusuyla sürdürülür: Bu nedenle, 
kesinlikle konuşursak, izole edilmiş bir hümanist diye bir şey yoktur. Bu, her alanın birbiriyle bağlantılı olduğunu ve dünyamızda devam eden hiçbir şeyin, hiçbir zaman dış etkilerden arındırıldığını ve saf olmadığını söylemektir. Hümanizm, insan emeğinin, insanın kurtuluş ve aydınlanma enerjisinin ve insanın kolektif geçmişi ve şimdiyi yanlış okumaları ve yanlış yorumlamalarının ürünü olarak daha fazla meseleyi eleştiriye tabi tutmaktır. Tamamen doğru, sorgulanamaz, hatasız bir tarih anlayışı olmamıştır. Hümanizm bunu eleştiri konusu haline getirir. Hümanizm insana dair olan her şeyin sorgulanması, alt edilmesi yeniden düşünülmesinin aracıdır. Hümanizm, tarihteki dil ürünlerini başka dillerde ve başka tarihlerde ortaya çıkarılmış dil ürünlerini anlamak, onları yeniden yorumlamak ve onlarla baş etmeye çalışmak için insanın dil yetisinin devreye sokulmasıdır. "Hümanist, insan zihninin insan zihnini sorgulama gücüne inanır. Tarih, kültür ve sosyo-ekonomik gerçeklikte yeterince yer alan bir bağlamda adaletsizlik ve acı çeken konular hakkında konuşmamız gerekiyor. Bizim rolümüz tartışma alanını genişletmektir. Hümanizmin dünyada haksızlıkların, despotizmlerin ve adaletsizliklerin ortadan kaldırılmasında ve özgürlüklerin elde edilmesi mücadelesindeki taşıdığı canlı ve değerli fikir potansiyellerinin hala cazibesini koruduğuna inanan Edward Said, değişimin insanın tarihi olduğunu; insanın tarihinin de insanın eylemiyle şekillendiğini ve buna bağlı olarak gelişen insani bilimlerin hümanizmin zeminini oluşturduğu kanaatindedir. Said’in bu düşüncesi esin kaynağı olan Vico'da en veciz ifadesini bulur:

Siyasi dünya hiç şüphesiz insanların eseridir; bu yüzden de ilkeleri kendi insani ruhumuzun değişikliklerinde bulunabilir ve bulunmalıdır. Bu konu üzerinde kafa yoran herkes şu durum karşısında hayrete düşmek durumundadır: bütün filozoflar ciddi ciddi doğanın dünyası hakkında bilgi edinmeye çalışmışlardır, halbuki bu bilgiye, yaratıcısı o olduğu için sadece Tanrı sahip olabilir halkların dünyasını ya da siyasi dünyayı ise ihmal etmişlerdir, halbuki bunu yaratan kendileri olduğu için insanların bu dünyanın bilgisini edinmesi mümkündür (Violan, 2010, s. 65).

Burada Vico'nun ve Said’in 'Sezar'ın hakkı Sezara, Tanrı'nın hakkı Tanrı'ya' anlayışıyla özetlenebilecek olan seküler çıkarımlarında, onların daima gözden ırak tuttukları bir husus vardır: Siyasi dünya insanın ürünü olsa da bu durum yine de bu dünyanın dinden yalıtılmış bir şekilde, her türlü dini ve manevi düşünceden steril olarak bir insanın eseri olduğu anlamına gelmemektedir. Dünya, insanın eseri olarak görülse de, tarihin her döneminde belirli düzeylerde varlığını belirli biçimlerde anlamlandırma ihtiyacı duyan ve bunun arayışına giren ve nihayetinde belirli bir inançta karar kılan inançlı insanların eseridir. Bütün bu eserlerin ve ona yön veren etkinliklerin ve motivasyonun gerisindeki din ve inanç boyutunu ihmal etmek, son derece yanlış olacaktır. Üstelik bu eserlerin içeriği, biçimi ve taşıdıkları sembolik anlamlar da mahiyeti kimi zaman meçhul bir yaratıcı, kutsal ve öte dünya anlayışını içermektedir.

Said’in eski bir öğrencisi olan R. Radakrishnan'a göre hümanizm ve eleştiri konusundaki değerlendirmelerine yakından bakıldığında, Said’in aynı anda iki soruyu gündeme getirdiği görülür: Teorik ve pedagojik. Teorik açıdan kendi içerisinde başlı başına bir tür ve estetik uğraş olarak ve pedagojik açıdan ise "eğitim ve öğretim konusu" olarak ve dış dünya ile ilişkisi bağlamında edebiyat yer almaktadır. Aynı şekilde hümanizmi teorik bir alan ve hümanistler aktif uygulayıcılar arasında da bir ayrım yapar. Hümanizmin teorik ve akademik bir olgu olarak görülme eğilimine karşı Said bu duruma karşı çıkar ve hümanizmin salt teoriden ibaret olup profesyonellik gerektiren bir uğraş olarak algılanmasının yanı sıra olduğunun teori eleştirisi ve Said'in profesyonellik eleştirisi karşılıklı olarak koordine edilmiş olarak görülmek zorundadır. Bu, Said'in hümanizmi alternatifler için bir olasılık olarak ve insani olanakların çokça genişlemesi olarak anlayan, yalnızca akademik-uzman bir bilgi paradigmasının seçkinliğine karşı koyma bağlamındadır (Radakrishnan, 2007, s. 27).

Edward Said hümanizmi dini, ilahi otoritelere karşı savunsa da hümanizm adına hümanizmi eleştirmenin mümkün olduğuna inanır. Ayrıca, Avrupa-merkezcilik ve imparatorluk deneyimiyle eğitim 
görmemiş zihin bulandırıcı etkilerine rağmen, kozmopolit ve metin-ve -dil bağlantısını yakalamış farklı türde bir hümanizm tasarlanabileceğine ve geçmişin büyük derslerini, örneğin Eric Auerbach ve Leo Spitzer ile daha yakın zamanlarda Richard Poirer’i özümseyerek, günümüzün yeni ortaya çıan -birçoğu sürgünde, yerinden yurdundan edilmişler arasında veya memleketlerinden uzaklaştıılmış insanlarda ortaya çıkmakla birlikte-sesleriyle akımlarına hala duyarlı kalınabileceğine inanmaktadır.

\section{Hümanizmin ve filoloji}

Hümanizmin çıkış noktası dildir. Dil, hümanizmi hem temel malzemesiyle donatır, hem de edebiyatla birlikte en zengin imkânlarını sunar. Dil insanların gündelik hayatlarını bir sisteme bağlayan, içinde yaşadığımız dünyaya ilişin bakış açımızı belirleyen ve ortak bir iletişim aracı olan; aynı zamanda sahip olduğu sözcüklerin ve kavramların yakın, zıt ve düz anlamlarıyla sosyo-kültürel alanları ilgilendiren politikaları büyük ölçüde belirleyen en önemli ögelerin başında gelir. Dışarıdan her hangi bir dayatmayı kabul etmemekle birlikte, o dili konuşan insanların bireysel ve toplumsal açıdan dünyayı kavrama biçimlerini sınıflandırma yetisine sahiptir. Dilin insanların anlayışına müdahalesinde olduğu gibi, dildeki kelimelere nüfuz ederek anlam katmanlarına ilavelerde bulunmak suretiyle söz konusu dili kullananların bir müdahalesi söz konusu olabilir. Dilin ve sözcüklerin yapıtaşlarını oluşturduğu edebiyat ise, bireysel, toplumsal ve kültürler arasında son derece eşsiz diyalektik ilişki biçimi geliştirmemize firsat verir. Dilin kendisi hümanizmi hem temel malzemesiyle donatır hem de edebiyatla en zengin imkânlarını sunar. Bütün diller, değişimler sonucu kendilerine yeniden hayatiyet kazandırarak var olurlar. Hümanizm ve eleştiri hemen bütün kültürlerde, değişmez bir bağla birbirlerine bağlı olup yeni olan şeylerin o dönemin sanatı, düşüncesi ya da kültüründe en yeni şekliyle gerçek ve heyecanlandırıcı olan eser ya da gelişmelerin önemli derece parçaları, ilişkisi ya da kabulü olmadan hiçbir büyük hümanist başarıya ulaşılamadığını görürsünüz (Said, 2004, s. 23).

Hümanizmin, edebi açıdan önde gelen fikirleri, on sekizinci yüzyllın sonlarında ve on dokuzuncu yüzyılın başlarında Almanya'ya geri döner. Bundan önce, İtalyan filozof ve filolog olan Giambattista Vico'nun fikirlerini daha sonra Goethe, Humboldt, Dilthey, Nietzsche, Gadamer ve yirminci yüzyll romantik filologları Erich Auerbach, Leo Spitzer ve Ernst Robert Curtius önemli katkılarda bulundular. Vico, Avrupa'da kendi döneminde Avrupa'da egemen olan felsefi düşüncenin rasyonel ve ampirik karakterde olması ve bunun da düşünsel ve felsefi kısırlaşmayı beraberinde getirdiğini görmüş bu dar kalıplardan çıkmanın çaresini aramış ve çözümü dil, din, şiir, sanat, hukuk, aile, devlet ve toplumun kökenlerine dair kapsamlı bir arayışın sonucuyla ortaya koymaya çalışmıştır. Onun çıkış noktası, bütün bu çok katmanlı yaklaşımla desteklenen bir filolojik perspektif olmuştur (Violan, 2010, s. 61). Günümüzde mazide kalmış gibi bir izlenim uyandırsa da filoloji, yorumlayıcı sanatların en temel ve yaratıcı olanıdır. Örneğin Goethe'nin genel olarak İslam'a olan ilgisine ve özellikle de Hafız’a, Bat-Doğu Divanı'nın kompozisyonuna yol açan tüketici tutkusu ve onun daha sonra dünya edebiyatı konusundaki düşünceleri bir bütün olarak incelendiğinde, Goethe'nin hem bireysel her bir sanat eserini kendi içinde değerlendirerek hem de bütünün görüşünü kaybetmeden korunduğu gibi bir senfonik bütün olarak dünya edebiyatının panoramasını ortaya koymaya çalıştığını görmek mümkündür. Dillerin ve tarihin pozitif bilgisi gerekliydi, ancak hiçbir zaman yeterli olmadı, örneğin gerçeklerin mekanik olarak toplanmasından daha fazlası, örneğin Dante gibi bir yazarın neyle ilgili olduğunu kavramak için yeterli bir yöntem teşkil ederdi. Auerbach ve seleflerinin hakkında konuşup pratik yapmaya çalıştığı filolojik anlayışın temel şartı, zamanının ve yazarının bakış açısıyla görüldüğü gibi yazılı bir metnin yaşamına sempatik ve öznel olarak giren bir şeydi. Başka bir zamana ve farklı bir kültüre yabancllaşma ve düşmanlıktan ziyade, 'Dünya Edebiyatı' (Weltliteratur) uygulanan filoloji, cömertlikle konuşlandırılmış derin bir hümanist ruh ve kuşatıcı anlayışı temsil etmiştir. 
Filolojinin, yazarın bireysel bir insan olarak ortaya çıkışında ve onunla diğer yazarlar arasında temel farklılığın bir işareti olarak belirleyici olmasında son derece önemli bir rolü bulunmaktadır. Bu da filolojinin, Edward Said'in ifadesiyle söyleyecek olursak, hümanizmin önemli unsurlarından biri olan yazarın biçemsel tercihlerini anlamada ve dolayısıyla metnin ana hatları ve ilişki ağı içinde kavrayarak yazarın yaşadı̆̆ı zamanı anlamamıza katkıda bulunur: "Bu nedenle, örneğin Conrad gibi bir yazarın okumanın, her şeyden önce, Conrad'ın kendi gözüyle sanki her kelimeyi, her bir metaforu, her bir cümlenin, Conrad tarafından bilinçli olarak herhangi bir sayıdaki diğer olasılıklar içinden seçilen bir tercih olarak anlamak demektir. Bundan ötürü, bu bilgi, onun okurları olarak bizi, onun kullandığı dilin içine girerek, bu dile özel olarak yaptı̆̆ tercihlerin sebebini anlayacak, eserlerini ortaya çıtığı haliyle anlayacak şekilde nüfuz ederek, karşılaştırmalı bir çaba harcamaya yöneltecektir. (Said, 2004, s. 62) . Filolojinin bileşeni olduğu hümanizm bu anlamda, alınan fikirler ve onaylanmış otorite yerine, insan bireysellik ve öznel sezginin kurumu üzerine kuruludur. Metinler, tarihsel âlemde dünyasal olarak adlandırıldıkları her türde üretilen ve yaşayan metinler olarak okunmalıdır. Fakat bu hiçbir şekilde gücü dışlamaz, zira tam tersine hümanizm tek kişi ve insanlık dışı uygulamalara ve insanlık tarihini bozan adaletsizliklere karşı son derece kararlı bir direnişin ifadesidir.

Filoloji, sağladığı empati anlayışı sayesinde kişinin düşünce dünyasında, bir yabancı olarak öteki için bir yer açar. İnsan zihninin belirsiz doğasından dolayı, cehalet içinde kaybolduğu her yerde insanın kendisini şeylerin ölçüsü kıldığı bir temel ilke konusudur. Ancak insan zihnin belirsizliği konusu hümanizmin tam anlamıyla güven duyulacak bir keskinliğe ve kesinliğe sahip olmasını engelleyen bir handikaptır. Bu handikap, filolojik öğrenme ve felsefi kavrayış disiplinleriyle tamamen olmasa da önemli ölçüde aşılabilir. Ayrıştırıcı, parçalayıcı ve indirgemeci olmayan, tam aksine bütünleştirici ve bütünleyici bir filolojik okuma yapmanın çok kültürlü toplumlarda dahi günümüzde önemli bir problem haline 'biz-onlar' temelindeki her türlü ötekileştirici söylem ve eyleme karşı çıkmak için temel bir koşuldur. Bu okuma biçimi çok daha kapsamlı bir entelektüel ve rasyonel bir yaklaşım olarak önemini korumaktadır. Ve dolayısıyla yabancı ve uzak kalacak olan bu ötekilere düşünce dünyamızda yer açma işi yorum yapan kişinin görevinin en önemli yönüdür. Örneğin küresel çaptaki toplumsal olaylar konusunda dahi protesto organizasyonlarıyla tüm dünyadaki alternatif toplulukların varlığı, alternatif bilgilerle bilgilendirilmesi ve buna bağlı olarak çevreye, insan haklarına ve özgürlükçü dürtülere karşı bilinçli bir şekilde farkında olmadan meydana gelmesi mümkün değildir.

Filolojinin özellikle on sekizinci yüzyıl sömürgecilik faaliyetleri ile birlikte İngiltere ve Fransa tarafından sömürgeciliği tahkim etme ve hegemonya kurma ve oryantalizmi üstünlük aracı olarak kurma noktasında ne ölçüde işlevsel bir araca dönüştürüldüğü görülmüştür. Bu noktada Said ve pek çok eleştirmen, dünyevi hümanizmin kapsam alanını eleştirel sekülerizmi içine alacak şekilde genişletti. Din ve sekülerizm arasındaki gerilimler, hümanist bir eleştirel sekülerizm yaratmaya yönelik en yeni girişimleri bile değiştirerek hümanizmi dönüştürmeye başlamıştır. Burada kaynağını ilahi veya metafizikten değil de insani olandan alan hümanist eleştiri, sekülerliği de benimseyerek gücünü pekiştirdiği gibi insani ve dünyevi olanın dışında başka her hangi bir kişi, kurum ve anlayışı reddederek edebiyatı dini içeriğinden soyutlamıştır. Emily Apter'e bakılacak olursa, göre Said’in eserindeki hümanizmin merkezi konumu, kısmen kendi düşüncesinin seküler temellerini korumanın bir aracı olarak anlaşılabilir. Hıristiyan bir ailede fakat Müslümanların çoğunlukta olduğu Filistin ve Mısır gibi ülkelerde yetişen Said, Musevilik de dâhil olmak üzere üç dinin arasında seküler bir tutumu benimser. Said'in bu tutumu kısmen anlaşlır olmakla birlikte, Apter'in ifadesine temkinli yaklaşmak gerekir zira Said, salt kendi düşüncesinin doğru çıkması adına değil bizzat inandığı ve asla ödün vermediği seküler anlayışın bir uzantısı olarak seküler hümanist anlayışı benimsemiştir. 
Filolojinin önermelerinin başında gelen okuma edimi, okumanın 'çağdaş hümanist'i son derece can alıcı önem taşıyan ve gerek alımlama gerekse direnme’ diye adlandırılan iki yönden kanalize ettiği ileri sürülebilir. Alımlamlayarak okuma, metnin kendisini insana açması olarak anlaşılan klasik anlamına karşın, insanın kendini bilerek metinlere açması ve metinleri, ilk başta geçici olarak, birbirinden ayrı parçalarmış gibi değerlendirip ki zaten insan metinlerle önce parçalı halleriyle karşılaşır, daha sonra, metinlerin içinde yer aldığı genellikle karanlıkta kalmış, ya da tam olarak anlaışılmamış olan yönleriyle birlikte ait oldukları tarihsel bağlama yerleştirmektir. Bundan sonra, metne anlam kazandıran belli eğilimler, duygular ve retorik yapılar, bağlamlarındaki bazı akımların iç içe geçmişini ve bazı tarihsel ve sosyal formülasyonlarını iç içe geçirerek ortaya çıkararak kendi zihninde genişletilmeli ve aydınlanmalıdır. Bu nedenle, edebi bir metnin yakından okunması, pratikte, metni, kendi ana hatlarında ve etkilerinde belirleyici bir rol oynayan tüm bu ilişkiler ağının bir parçası olarak kendi zamanına yerleştirmektir. Ve benim görüşüme göre, hümanist bakış açısına göre, ilk önce okuma eyleminin, bir dizi karar ve tercihin sonucu olarak yazıyı gerçekleştiren yazarı konunun konumuna getirme eylemi anlamına geldiğini söylemek önemlidir. Herhangi bir yazarın, kendi yaşamının zamanına, yerine ve koşullarına hükmedip durduğunu söylemek mümkün görünmediğinden, bunların, yazarın kendisine sempati duymasına yol açması olarak anlamak gerekir. Oryantalizm, mücadele alanlarını açmak için hümanist eleştiriyi kullanmak, bizi hapseden kısa, kısa ömürlü, düşündürücü patlamaların yerini alacak daha uzun bir düşünce ve analiz çizgisi oluşturmak için yararlanılabilecek bir mecradır. Öncelikle, hümanizmle, beyni tarihsel ve rasyonel olarak yansıtıcı bir anlayış için kullanmak için Blake'in zihin kelepçelerini çözme denemesi akla geliyor. Dahası, hümanizm, diğer tercümanlarla ve diğer toplumlarla ve dönemlerle bir topluluk duygusuyla korunur: Bu nedenle, izole edilmiş bir hümanist diye bir şey söz konusu değildir.

\section{Hümanizm, sekülerizm ve din}

Hümanizme yönelik eleştirilerin başında din veya Allah inancı olmadan, varlığımızın ve hayatın anlamından söz edilip edilemeyeceği sorusu gelmektedir. Eleştirilerden bir diğeri insanın gizemli yapısını göz ardı ettiği yönündeki yaklaşımdır. On dokuzuncu yüzyılda da sıkça sorulmakla birlikte, söz konusu sorular yirminci yüzyılda da hayatın anlamı biraz daha ayrıntı kazanarak, bir amacı olup olmadığı, hayatın anlamlı mı yoksa anlamsız olduğu bir şekle bürünmüştür. Din, bireyin yaşamının, genel bir ilahi plana veya amaca nasıl uyduğunu ortaya çıkarmak iddiasındadır. Evrenin doğası ve orijini ile içindeki yerimizin, bireylerin yaşamlarına şekil, yapı ve amaç verebilecek gibi görünen genel bir teorik anlatımını sağlar. Bu nedenle, dine inananların sık sık sadece dinin bunu yapabileceğini, öte yanda dini inancı olmayan bir yaşamın anlamsızlığa mahkûm edilmiş bir yaşam olduğunu iddia etmeleri şaşırtıcı değildir (Norman, 2004, s.140).

Hümanizm bilimsel ve rasyonel gerekçelerden hareketle, biz insanların duyusal organlarımıza ve beynimizin yapısına bağlı algısal ve entelektüel kapasitelerle sınırlı olduğumuzu düşünür. Bu nedenle, hümanist anlayışa göre biyolojik yapımızın, kendimizi anlamanın dışında içinde yaşadığımız dünyanın başka niteliklerini anlama konusunda bize başka bir şekilde katkı sunmaz. Hümanizm zihni kutsallaştırmaz (Norman, 2004, s.134). Öyleyse dinlerin, gizem duygusunun duygusal boyutu üzerinde tekelleri yoktur. Hümanizm sayesinde insanın entelektüel sınırlarının tanınması, dini inançların öngördüğünden daha kolay anlaşllabilir. Eğer "ruhsal” kelimesinin, eksikliğini hissettiğimiz önemli bir şeye işaret ettiği düşünülürse, o zaman insan yaşamına derinlik kazandıran şeyin ne olduğu sorusu ortaya çıar. 'Ruhu yükselten', hayatı yaşamaya değer kılan şeyler nelerdir? Hümanizm onları dışlar mı? Hayır. Yine, banallığa düşme riskini alıyoruz, ama hepimiz bu şeylerin ne olduğunu deneyimlerden biliyoruz. 
Hümanizm, çeşitli şekillerde "dünya görüşü”, "hayata yaklaşım”, “yaşam”, "tutum”, “yaşam biçimi” ve "anlam çerçevesi” olarak adlandırılmıştır. Tüm bu ifadelerin, onları öneren yönleri vardır. Hiçbir şey insan sorusundan muaf değildir. Bu, pozitivist bilginin tanımına uyan hiçbir bilginin olmadığı, bu sorgulamadan muaf tutulmuş hiçbir gelenek, vahiy, otorite, imtiyazlı bilgi ilk ilkeler, sezgiler, aksiyomlar olmadığı ve deneyimsiz bilgi olamayacağı anlamına gelir.

\begin{abstract}
Hümanizm, bireyler ve toplum için neyin doğru olduğuna odaklanarak politik teorileri desteklemeye çalışır, ancak belirli siyasal teorilerle birleştirilmez. Toplumun hümanist vizyonu, "iyi yaşam" in tüm bireyler için ve dolayısıyla bir bütün olarak toplum için mevcut olduğu bir düşüncedir. Bu, bir kişinin sahip olduğu sınıf, renk, rrk, cinsiyet veya statüsü ne olursa olsun, demokratik olarak, içindeki tüm bireylerin özgürlüğünü, refahını, yaratıcılığını ve yerine getirilmesini teşvik edecek türden koşullar yaratacak bir toplumdur. Yüksek yaşam standartları, dünya demokrasisi, barış ve gelişen bir ekonomi vizyonuna sahiptir. Sağlam sağlık, tatmin edici çalışma, ekonomik güvenlik, eğitim firsatı, kültürel zevk, yeterli rekreasyon ve birinin yaşamın tatmin edici ve yerine getirilmesi için ifade etme özgürlüğü, hümanistin en iyi toplumsal yaşam türü olarak gördüklerinin tüm yönleridir. (Fowler, tarih, s. 175.)
\end{abstract}

Hayata bakış açım tamamen anlamsız. Sanırım kötü bir ruh burnumun üzerine bir çift gözlük koydu, bunlardan biri lensi çok güçlü bir büyüteç, diğeri eşit derecede güçlü bir indirgeyici cam. (Thomte, 2009, s. 29)

Hayat çok boş ve anlamsız. - Bir adamı gömüyoruz; Onu mezara kadar takip ediyoruz, üstüne üç kürek toprak atıyoruz; bir taşıtla mezarlığa gideriz, taşıtla eve gideriz; önümüzde uzun bir yaşamın olduğunu düşünerek rahatlarız. Yetmiş yll ne kadar sürecek? Neden bir kerede bitirmiyoruz, neden kalmıyor ve dünyada üç kürek toprağı atan son mutsuz kişiyi ve üzerine toprak atılan son kişiyi görmek için onunla birlikte mezara inmiyoruz? (Kierkegaard, 1843, ss. 28-29)

Bu durumun nedeni, on dokuzuncu yüzyllda dini inancın genel krizidir. Schopenhauer ve Nietzsche gibi filozoflar, görevlerini itibarını yitirmiş olan Hıristiyan inançlarının yerine geçebilecek ve yaşamlarımızı yönlendirebilecek bir deneyim ve yorumlama sağlayacak bir yaşam felsefesi sunmak olarak görürler. Tolstoy, romanları Savaş ve Barış'ta, Pierre Bezukhov yaşamın anlamını arayan Anna Karenina'da Levin ve otobiyografik çalışması olan Bir İtiraf'ta, kendi anlam krizini ifade eder:

Bilginler tarafından bize sunulan rasyonel bilgi, yaşamın anlamını reddeder, ancak insanlı̆̆ın tamamı olan muazzam insan kitleleri, bu anlamı irrasyonel bilgiden alır. Ve bu irrasyonel bilgi inançtır, benim için reddedilmeye mahkûmdur. Tanrı, teslis; altı günde yaratma; şeytanlar ve melekler ve diğerleri aklım olduğu sürece kabul edemeyeceğim şeylerdir (Tolstoy, 1940, s. 47).

Hümanizm ile sekülerizm ve din arasındaki ilişkiyi bir bütün olarak olanca karmaşıklı̆̆ıyla ele alan Charles Taylor olmuştur. Onun bu alandaki çalışmalarını yakından incelemekle, hümanizm konusundaki tartışmaları öğrenme fırsatı bulduğumuz gibi aynı zamanda söz konusu kavramın ortaya çıkışından bu yana geçirdiği evrimi anlamak açısından oldukça önemlidir. Taylor, "esasında büyük ölçüde dinsel inancın modern Batı'daki yazgısını inceleme çabası” olarak nitelediği (Taylor, 2007, s. 510) A Secular Age (Seküler Çağ) adlı çığır açan kitabında hümanizmin günümüzdeki durumunu, tarihsel olarak din ve seküler kültür arasındaki ilişkiyi, teoloji, dogma, popüler inanç, ruhsallık, bireysellik, akıl, dindarlık gibi unsurlarla şekillenmiş ve bir gelenek haline gelmiş olan biçimini irdeler. Taylor’a göre hümanizm; bireysel özgürlük, evrensel insan hakları, anti-emperyalizm, ekonomik bağllıktan kurtulma ve hakları elinden alınmış insanların kendi geleceklerini tayin etmeleri gibi değerlerin hayatta karşılık bulma konularıyla ilgili olduğu kadar din ve sekülerizm kavramlarıyla birlikte yan yana düşünülmeye başlanmıştır. Modernite ile din arasındaki bilinen ilişkiyi hatırlayacak olursak, modern olabilmek için eski, geleneksel inançları bir tarafa bırakmak gerekir. Sekülerleşme en azından kısmen, kilise rahiplerince klasik yazarlara ve eski çağ metinlerinde bulunan ve ancak kabul edilmeyen atıflardan, ayrıca on beşinci yüzyıl hümanistlerince klasik sözlere inanışlarını yasalaştırmak için kullanılan 
atıflardan doğmuştur. Ancak içinde bulunduğumuz dönemde, hem Tanrı'ya inanmak hem de modern çağda yaşamanın olasılı̆̆ı bulunmamaktadır. İnanmayı sürdürmek, modern olmamanın göstergesidir. O halde Tanrı'nın varlığını yadsımakla modern dünya görüşüne ulaşlabilir. Ancak Taylor bu noktada sekülerizmin, insanın ve toplumun yararına olduğunu düşünerek Yahudi-Hıristiyan dünya görüşlerinin kimi unsurlarını korumaktan yana tavır alır. O, materyalizmin hala dünyada taraftar toplaması ve önemli ölçüde gücünü ve geçerliliğini korumasında, bilimin lehine olmak üzere dini hayattan kovmasından çok, dayandığı etik dünya görüşünün etkisi olduğunu düşünür. Aynı şekilde sekülerizmin, kaynağının dini olup olmamasına bakılmaksızın varlığını ve etkin konumunu sürdürmesinin yolu, kendi özgün etik değerlerine yaslanmasıdır. Taylor, sekülerleşmeye yol açan unsurun Hıristiyanlık içindeki bir yer değiştirme olduğunu, bunun da değerlerle yüklü bir hümanizmle sonuçlandığ görüşündedir. Böylelikle Taylor sekülerleşmeye dini bir içerik kazandırmak için çaba sarf ederken öte yandan Hıristiyanlık tarihini aşkın içeriğinden soyutlayarak ve dinsel bir çerçeve dışında benimsenip uygulanabilecek yeni bir toplumsal düzenin temeli haline getirmeye çalışır. Artık Tanrı'ya akılla inanmıyorsak, başlangıç noktamız, modern çağın etik dünya görüşüdür. Seküler toplumlardaki kamusal yaşamımızın tek kaygısı insanın iyi durumda olmasıdır. Bazı insanlar böyle bir dünyada Tanrı inancına yer olmadığını düşünür. Bu tür inanç kişiyi ister istemez yabancı bir dünyanın düşmanı haline getirecektir. Kişi ya bu dünyanın bütünüyle içindedir, bu dünyanın öncüllerine göre yaşar, dolayısıyla da Tanrı'ya gerçekten inanması mümkün değildir, ya da inanır ve bir anlamda modernite içinde yabancı gibi yaşar. Kendimizi gittikçe daha fazla modernite içinde bulduğumuzdan, inanç gittikçe daha zor hale gelir; dinin ufku bizden sürekli uzaklaşır.

Taylor'a göre hümanizm, uygarlık kriterleriyle tanımlanan bir Hıristiyanlık anlayışının uzantısıdır. Hümanizm, kurumsal bir dinin Hıristiyanlığa müdahalede bulunarak modern ahlak düzeninin yolunu açmıştır. İnsanların toplumsal olarak sorumluluk sahibi olmalarından kaynaklanan bir inanca duyulan güven, insan iradesinin bir eseri olmasından çok ilahi amacın bir ifadesi ve devamı niteliğindedir. Taylor, Hıristiyanlıkla bağlarını koruyan bir iç muhalif akım olarak Hıristiyanlığa akla ve insan iradesine dayalı doğru davranışı tanımlarken diğer yanda ilahi inayet anlayışına karşı çıkar. Kökünü; Hıristiyanlıktan alan bu hümanizm, Taylor’a göre, Hıristiyanların kem taraftarlarını hem de karşıtlarını uyum içinde içerecek kadar geniş kapsama sahiptir. Dolayısıyla Taylor'ın çıkarımına göre hümanizm ve sekülerizm, aklı ve insan iradesini öne çıkarmadıkları için kusurlu olan Hıristiyanlığın mükemmel hale gelmiş olan şeklidir. Ancak paradoksal olan durum sekülerizmin kendi varlığını korurken Hıristiyanlıktan gücünü almasıdır.

Hümanizm ve din arasındaki ilişkinin biçimi ve düzeyi konusunda Taylor’ın düşünceleri son derece dikkat çekicidir. Salt hümanizmden yana tavır alıp dini dışlamadığı dini cepheye arka çıkarak hümanizmi aynı şekilde hükümsüz bırakmaktan da yana değildir. Bu konuda her iki tutumun bir birlerine karşı ön yargılı ve dışlayıcı olmamaları gerektiğini, her iki olgunun haklı yönlerini gerçekçi bir şekilde kabul etmek gerektiğini düşünür: Aydınlanma anlatısının hem hümanizme hem de dine yeni açılımlar getirdiğini, dinin görece bu durumdan yara aldığını “...ancak yine de dışlayıcı hümanizmin benimsediği, yaşamın metafizik üstünlüğü fikrinin yanlış bu boğucu olduğunu ve onun süregelen egemenliğinin pratik üstünlüğünü tehlikeye düşürdüğünü” düşünür (Taylor, 2007, s. 637). Hümanizm ve dinin bakış açılarındaki problemleri dile getiren Taylor, önce hümanizmin sorunlu yönünü ortaya koyar: Dışlayıcı hümanizm aşkınlık penceresini, ötede başka hiçbir şey yokmuşçasına kapatır. Ayrıca hümanizmin burada insanın içinden gelen en derin kalbi özlemi değilmiş edasıyla yapar. Hatta bu ihtiyacı duymak bir hatanın, yanlış bir dünya görüşünün, önyargılı koşullanmanın veya daha da kötüsü, bir patolojinin sonucuymuş gibi davranılır (Taylor, 2007, s. 638). Taylor, dini bakış açısının problemi oluşunu ise şu argümanla ilişkilendirir: Aşkınlığın reddi, bütün ahlaki standartların eninde sonunda 
ortadan kalmasıyla sonuçlanacaktır. Önce seküler hümanizme, ardından da onun dine gösterdiği saygıya ve değerlerine meydan okunacaktır ki bunun da sonu nihilizmdir. Taylor, dinin bu söylemle ölümü ve şiddeti bir değer haline getirmesi endişesini taşıdığı kanaatindedir (Taylor, 2007, s. 638). Peki, o halde hangi tutum haklıdır? Taylor'ın kendisine sorduğu bu sorunun cevabının, hayatımızı hangisinin daha anlamlı hale getirdiğinde yattığını ortaya koyar. Buna göre, dinin varlığı dahi seküler veya dışlayıcı hümanizmi çürütmeye yeterlidir. Fakat bu durumda dinin öte dünya lehine ölümü ve şiddeti yüceltmesi karşısında ne yapmalıyız? Öte dünyanın, en eski dinlerde bariz bir şeklide görüldüğü üzere, bu iki şiddet sarmalını teşvik ettiğini düşünmekle birlikte, tam tersi bir durumun da var olduğunu René Girard'dan öğrenmiş bulunuyoruz. Girard'ın, iyi bir öte dünya beklentisinin neden olduğu iyi davranışların davranışlarımıza olumlu yönde yön verdiğini bunun da sonuçta iyi bir hayatı ve dünyayı temin ettiğini düşünür (Taylor, 2007, s. 639).

Martin Heidegger hümanizmin her şeyden önce inşa ile ilgili boyutuna dikkat çekerek bu kavramın tanımının özünde insanın yattığını düşünür. Şöyle ki; Sözcüğün içindeki "humanum", humanitas'a, insanın özünü sürdürmesine işaret eder. "-İzm" ise, bir yönteme ve iradeye işaret ederek, insanın özünü sürdürmesinin önemli bir şekilde ele alınmak istendiğine atıfta bulunur. "'Hümanizm", sözcük olarak bu anlama sahiptir. Ona anlamını geri vermek demek, ancak sözcüğün anlamını yeniden belirlemek demek olabilir. Bunun için de önce, insanın özünü sürdürmesinin tecrübesi daha köklü olarak edinilmeli; sonra bu özün, kendi tarzına ne ölçüde uygun olduğu gösterilmelidir. (Heidegger, 2013, s. 37) Hümanizm, kendi şartlarına göre özel bir etkinlik olabilir, ancak "insancıllık" ve hümanizmin esası olduğu insanlık, temel, organik ve genel bir gerçektir.

Heidegger öncelikle hümanizmin insanın esas olarak bir değer konusu ele alınması ve onun karşısında Tanrı, din ahlak gibi kavramların da göreceli olarak değerden arındırılması düşüncesini eleştirir. Ona göre 'değerler'e karşı olan düşünme, 'değerler' diye kabul edilen 'kültür', 'sanat', 'bilim', 'insan onuru', 'dünya', 'Tanrı'nın değersiz olduğunu iddia etmez. Tam tersi, artık nihayet kabullenme zamanı gelmiştir ki, bir şeyin 'değer' diye adlandırılmasıyla, öyle değerlendirilenin aslında onuru yok edilmektedir. Şöyle ki: Bir şeyin değer olarak görülmesiyle birlikte o, değerlendirilene, onun sadece insanın değer biçmesinin nesnesi olmasına izin veriliyor demektir. Oysa bir şeyin kendi Varlığı içinde olması, onun nesnelliğiyle tüketilmez, hele hele nesnellik, değer karakterini almışsa hiç tüketilemez. Olumlu değerlendiriyor olsa da her türlü değerlendirme bir özneleştirmedir. Değerlendirme varolanın olmasını sağlamaz, onu sadece kendi yapıp etmelerinin nesnesi olarak geçerli kılar. Değerlerin nesnelliğini kanıtlamaya çalışan bu tuhaf çaba ne yaptığını bilmemektedir. Ve nihayet 'Tanrı' 'en yüksek değer' olarak ilan edildiğinde bu, Tanrının özünün aşağılanmasıdır. Değerlendirerek düşünmek, burada ve her yerde, kendini Varlığa karşı düşündüren en büyük haksızlıktır. Bu nedenle değerlere karşı Düşünme, değersizlik için ve Var olanın hiçliği için davul zurna çalmak yerine, şu anlama gelir: Var olanın özneleştirilerek sırf bir nesne yapılmasına karşı Varlığın Hakikatinin Işımasını Düşünmenin önüne getirmek. "Dünya-İçinde-Olmak" ifadesinin, homo humanus'un humanitası'nın temel özelliği olması, insanm Hıristiyanlıkta anlaşıldığı şekliyle sadece dünyevi bir varlık olarak Tanrıya yüz çevirmiş, hatta 'aşkmlık'tan kopmuş olduğunu iddia etmez. Bu sözcükle, Transcendente'nin adlandırabileceğinden daha anlaşılır bir şey kastedilir. Transcendente, duyusal olanı aşan Var olandır. Bu, bütün Var olanın ilk nedeni anlamındaki en yüksek Var olan için geçerlidir. Bu ilk neden olarak Tanrı düşünülür. Oysa "Dünya-İçinde-olmak"taki 'Dünya' kesinlikle ilahi olandan farklı biçimde fani Var olan anlamına gelmediği gibi, 'tinsel' olandan farklı olarak 'dünyevi' olan anlamına da gelmez. Bu belirlemede 'dünya' hiçbir şekilde Var olan ve Var olanın alanı anlamına gelmez, Varlığın Açıklığı anlamına gelir. İnsan var olduğu sürece vardır ve insan olarak vardır (Heidegger, 2013, ss. 41-42). 
Din, dini metafor olarak veya metafora başvurarak dindar olmayana dini anlatabilir. Ya da her yerde hazır ve nazır Tanrı anlayışını kabul etmeyen kimseler buna kaynak olur. Roman ise agnostik olmalı (Lerner, 1967; Faulkner, 1975, s. 5). Fakat din de insani bir durumun tercümanıdır. Hümanist sebep açısından dindarlardan farklıdır. Buna göre hümanist referansını akıldan, dindar İlahi olandan alır. Biri ahlakını insani, diğeri imani, ilahi olandan alır. Hıristiyanlıkta teslis inancı esas olup Hıristiyan kendisinden çok Hz. İsa’ya bağlıdır. Dindar gücü kendisinin dışında bulur. Hümanist ise din ve dini söylemler konusunda kuşkuludur ve bundan dolayı araştırmaya daha yatkındır. Hümanist nihilist değildir, ancak, kuşkunun sınırları, değerleri, ilişkileri, faaliyetleri vardır.

\section{Din ve edebi anlatılar}

Hümanizm ve din çatışmasının kökenine bakıldığında, iki olgunun aynı amacı paylaştığı ve çatışmanın bu amacı gerçekleştirme yolunda bu iki yolun farklı önermelerde bulunmasından ileri geldiği anlaşılır: Hayatın anlamı nedir? Din ve inanç olmaksızın hayatın anlamı ve amacı var mı? Hümanizm, hayatın yalnızca din ile anlamlı olduğu düşüncesine karşı çıkarak sanat ve edebiyatın hayata anlam kattığını ve onu anlamlı kıldığını ileri sürer. Hümanizmin daha güçlü bir şekilde iddia ettiği konu şudur: Sanat geleneksel dinin yerini veya dine indirgenmiş versiyonu olarak sekülerizmin bıraktığı manevi boşluğu doldurur. Dini inancın kendisi ise yalnızca anlatıların özel bir durumudur. Hikâyeler, hayatımızı biçimlendirir ve onlara anlam kazandırır. Edebiyat ve diğer sanatlar, kendi kendine yeten arayışlar olmayıp, aynı zamanda nasıl yaşamamız gerektiği hakkında düşünmemizde bize yardımcı olabilecek fikirler sunar, deneyimlerimizi şekillendirerek yaşamlarımıza anlam katmamızı sağlarlar. Bu da sanatı hem benzersiz hem de değerli kılar. Estetik formu takdir etmenin, estetik olarak tatmin edici kılan bir çalışmanın niteliklerinin aynı zamanda kendi tecrübelerimize şekillendirme ve önemli bir yapı verme yollarını ortaya koyar. Edebiyata anlamını veren ayırt edici özelliği, yaşamlarımıza anlam katma kapasiteleridir. Bunu iki şekilde gerçekleştirir: (1) Edebiyat 'paradigmalar', aracıllı̆ıyla genelleştirilebilir örnekler sağlayarak kendi tecrübelerimizi aydınlatabilir ve anlamlandırabilir, ama (2) sadece hikâye oldukları ve karakterlerini temel alarak yapabildikleri için okurları ikna eder ve böylece bu örneklik vasfını hayata geçirir. Doğru bir hikâye edinmenin yollarına ihtiyacımız var, böylece deneyimle doğruluğu test edilmiş davranışları tekrar edebileceğimiz gibi, aynı şekilde yanlış davranış kalıplarını da tekrar etmekten kaçınmış oluruz. Bütün iyi terapi ve danışmanlık örnekleri başarılı hikaye konusuna öncelik verirler; ama dini inanç konusunda farklı olan şey, dini hikayelerin bütün insanlığın ortak doğru hikayesi olduğu ve kişisel hikayelerin bu hikayeler ile uyumlu olmasının beklenmesidir. Aksi halde kişisel hikâye bir anlam ifade etmeyecektir (Norman, 2004, s. 154).

Hümanizm, insan iradesi ve eyleminin formel bir başarısıdır; her ikisinin de işleyişine ne kadar inanırsak inanlım, 'piyasa' ya da 'bilinçdışı' gibi bir sistem ya da gayri-şahsi bir güç değildir. Diğer yanda hümanizm ve edebiyat neredeyse anakronik bir yaklaşımla güncel sorunlara ilgi göstermeyen donuk ve heyecansız bir uğraş olarak addedilmiştir. Hümanizmi anlamak, onu tüm sınıf ve kökenlere açık, demokratik bir akım ve hiç sonu gelmeyen bir ifşaat, keşif, özeleştiri ve kurtuluş süreci olarak anlamak demektir. Hümanizm eleştiri demektir, bu eleştirinin gücünü ve etkisini, demokratik, seküler ve açık karakterinden alır. Vico bireysel ve dünyevi eylemlerimizin seküler yapısını doğasını ifade ederken, bizim gerçekten yalnızca yaptığımız şeyleri ancak onların yapılış şekillerine göre bilebileceğimiz doğrultusundaki seküler düşünceye dayanmaktadır. Bir tarihin içinde yaşayan insanlar olarak bizler, yaptığımız şeyleri biliriz; yani, bilmek, bir şeyin nasıl yapıldığını bilmek onu, onu yapan insanın bakış açısıyla görmek demektir. Vico da bilgiyi tarihsel bakış açısıyla ve etkin olarak almak şeklindeki yeteneği esas almaktadır. Edward Said'e göre insani bilimler, seküler tarih, insan emeğinin ürünleri ve insanın düşüncesini ifade etme yeteneğiyle ilgilidir. Vico'nun sadık bir öğrencisi olan Auerbach, Avrupa 
merkezci bir misyona sahip olmakla birlikte, insanın tarihinin ortak bir paydaya ve birliğe sahip olduğunu da kabul eder ve edebiyat ile birlikte tarihin, teolojik yorumlardan uzak bir şekilde erkekler ve kadınlar olarak insanların eseri olduğu düşüncesini kabul eder. Ona göre, modern milliyetçiliklerdeki ve kültürlerdeki güçlü savaşma eğiliminin baskın olmasına ve birbirlerine düşmanca duygular besleyen öteki kültürlerin ve ulusların birbirlerini anlama becerisi geliştirebileceğini; eksik, yanlış, yetersiz ve taraflı bakış açılarının farkında olmanın kişiler için olduğu kadar toplumlar için de sağlıklı bir kavrayışı beraberinde getirerek uzak ve öteki olarak nitelenen bir edebiyatın incelenmesini son derece mümkün kılmaktadır. Dolayısıyla entelektüellerin bir amacı da çatışma alanlarından ziyade, birlikte yaşama alanlarını kurmaktır. Sömürgecilik ve sömürgecilik sonrası bağımsızlık süreçlerinden çıkarılması gereken derslerden birisi bu olmalıdır. Bu bakımdan Goethe'nin karşılaştırmalı edebiyat fikri, dünyanın tüm edebi üretiminin, ulusal sınırları ve dilleri aşmakla birlikte tek tek parçaların tekilliğini ve tarihsel gerçekliğini hiçbir zaman ortadan kaldırmadığı gerçeğine dayanır. Hümanizmin en önemli parçası ve bileşeni olduğu edebiyat eserlerinde, bireysel yaşamları ve toplumsal dokuları bir arada sunma ve yansıtma olanağı bulduğunu düşünen Auerbach, edebiyatın insanların hayata dair görüş ve deneyimlerini yansıtmakla birlikte yaşamın her daima bireysel sınırlılıkları aştığını ve bütünüyle kavranamayacak kadar zengin ve karmaşı olduğuna dikkat çeker.

Bu denli zengin ve karmaşık bir olgu olan hayatın kendisinden ortaya çıkan büyük bir yaşamsal düzen ve yorum bulunmaktadır. Bu düzen ve yorum bireylerin kendi içinden doğar ve daha örtük bir şekilde bireylerin söz ve fiillerinde vardır. Zira içimizde sürekli bir formülasyon ve yorumlama süreci devam etmektedir. Bu sürecin konusu daima kendimizdir. Hümanizm bir ölçüde kabule direniştir ve her türlü klişe ile düşünmeyen dile karşı koymayı gerektirir. Hümanizm, sağladığı bilgi birikimi ile ulusal farklllıkları ve Huntington'ın "medeniyetler çatışması" tanımında ifadesini bulan kutuplaşmayı ve düşmanlığı, birbirlerini karşılıklı tanıma ilkesi temelinde yeniden konumlandırarak, dostluk anlayışına evrilmesini sağlayabilme potansiyeli taşır. Edebiyatta ifade edilen özgünlük, duyduğu duygudan kaynaklanmaktadır.

\title{
Hümanizm ve edebiyat
}

\begin{abstract}
Edebiyat akla gelebilecek en güçlü savları dikkatine sunar, çünkü diğer sanat ya da ifade formlarından daha fazla yapılabilecek olan şeyleri, hayatın günlük akışında herkesin kullanıp paylaştığı bir meselede neler yapılabileceğini, bunların yanı sıra, bir toplumun toplumsal siyasal ve ekonomik düzenlemelerine yön veren varsayımları kendi kelime dağarcı̆̆ı ve sentaksıyla, kendi içinde en ustalıklı ifadelerle ve yine de ölçülü biçimde yansıtan bir meselede nasıl adım atılabileceğini gösterir. ... Ancak edebiyat (müzik, dans resim ya da sinema eserlerinden farklı olarak) kendi ilkesi veya özsel kaynağı olarak, genelde toplumla ve o toplumun tarihiyle tam bir ortaklıkla paylaşması gereken malzemelerden beslenir. Hiç kimse bize kelimelerin öğrettiğinden daha fazla şey öğretemez, bu yüzden biz de, kelimeler aracılığıyla, belki de onlara anlamlarını veren şeylerin düzeninde değişiklik gerçekleştirecek bir şeyler yapmaya çalışmalıyız. Okuru kelimelerle, başka hiçbir şeyde mümkün olmayacak derecede yoğun bir diyalektik ilişkiye davet etme ayrıcalığı edebiyata düşer (Poirier, 1987, ss. 133-134).
\end{abstract}

Poirier, oldukça iyi işlenmiş olan bu paragrafta edebiyatın diğer sanatlarla olan ilişkisini dile getirmekle birlikte onlara karşı edebiyatın ayrıcalıklı konumunu ve üstünlüğünü hem içerik hem de şekil açısından irdeler. Edebiyat hem bireysel açıdan hem de toplumsal açıdan insani olan her duygu, düşünce ve yaşantının konu edilebildiği bir sanat dalıdır. Bireysel açıdan konumu, uğraşları, yaşam tarzlarıyla toplumun en alt tabakasından en üst tabakasına en varlıklı bireyin sıra dışı yaşamından en sıradan insanın en sıradan bir yaşantısını birlikte, yana yana aynı kompozisyonda dile getirmekle birlikte, bireyselliğe yaptığı vurgu kadar içinden çıktığı toplumu da göz önünde bulunduran dolayısıyla toplumun da yansımasını bulabildiğimiz yegâne sanat türüdür denilebilir. Yazar ve şair, edebiyatın malzemesi olan 
dil ve kelimeler aracılığıyla hem toplumu yansıtır hem de bize bireysel bir tercih olan kelime seçimi ile üslup sahibi olduğunu dolayısıyla edebiyat alanındaki yetkinliğini de görme imkânı sunar.

\begin{abstract}
Hümanizm okumayla ilgili, perspektifle ilgili bir şeydir ve hümanist olarak yürüttüğümüz faaliyetlerde, bir alandan, yani insan deneyimleriyle ilgili bir sahadan başka bir sahaya geçmekle ilgilidir. Ayrıca hümanizm, o dönemin bayrağının veya ulusal savaşın getirdiği kimlikler pratiği ile ilgili bir şeydir. Alternatif bir kimliğin bu şekilde kullanılması, okuduğumuz ve metnin parçalarını başka parçalarla ilişkilendirdiğimiz ve dikkat gösterdiğimiz alanı onunla ilgili başka halkaları da içine alacak şekilde genişlettiğimizde yaptığımız şeydir. Hümanizm hakkındaki her şey, onsuz gerçek bir edebiyatın olamayacağı, onsuz edilmeye değer hiçbir lafın edilemeyeceği ve koruyup teşvik edilmeye layık bir insanlık tarihi ve eyleminin söz konusu edilemeyeceği şekilde ve ancak bireyin kendisinde başlayabilecek derece inatçı bir inanca dayanmaktadır (Said, 2004, s.83).
\end{abstract}

"Kanaatimce hümanizm, sözcüklerin uzamı ile onların fiziksel ve toplumsal düzlemdeki çeşitli köken ve kullanımları(...) arasındaki nihai antinomik ya da çatışkılı çözümlemesini sağlayacak olan yegâne araç ve bilinçtir. Bütün bunlar dünyada, günlük hayatımızın tarihimizin ve ümitlerimizin temeli üzerinde cereyan eden şeyler olup, arayışımız hikmet, ve adalet ve belki de özgürlük yönündedir" (Said,2004, s.80).

Said’in de dikkat çektiği üzere hümanizm edebiyat aracılığıyla günlük hayatımızı, beklentilerimizi kuşattığı gibi bireysel ve toplumsal düzeyde onu anlamlandırma bakımından en önemli katkıyı sağlar. Burada "hümanizm, insan hayatının manevi boyutunu dikkate almaz" görüşüne karşı çıkar ve 'Bir hümanistin hayatı zenginleştirici ve anlamlı bulmasının yöntemine " işaret eder (s. 139). Hümanistler, pek ala, inananlar kadar yaratıcı başarının zevklerinden, keşif heyecanından, insan ilişkilerinden, sanat ve doğanın güzelliklerinden zevk alabilirler. O halde dini inanç buna nasıl katkıda bulunabilir? Norman'ın temel savı hümanizmin hayatımıza anlam kattığı yönündedir (Norman, 2004, s. 139). Ancak Norman, sanatın bunu eşit derecede iyi sağlayabileceğini savunuyor. Hayata anlatının anlam verdiğini, bu açıdan dini hikâyelerin aynı işleve sahip olduğunu ifade eder. "Sanat, özellikle edebiyat ve diğer anlatı sanatları, dinin yalnızca doldurmayı iddia ettiği bu rolü üstlenebilir ve yapabilir" görüşündedir. Norman, sıklıkla başvurulan "Dini inancın kendisi, anlatıların, hikâyelerin, hayatlarımızı biçimlendirme ve anlam verme biçimlerinin özel bir örneğidir” argümanını böylece tersine çevirir (Norman, 2004, s. 146). Norman için "takdir etmek... estetik açıdan tatmin edici kılan bir çalışmanın niteliklerini, aynı zamanda kendi tecrübelerimizi şekillendirme ve onlara önemli bir yapı kazandırma yollarını tanımaktır" (Norman, 2004, s. 148). Norman'ın hayran olduğu hikâyeler 'paradigmatik özgüllük' olarak adlandırdığı şeyi somutlaştırdı; onlar belirli insanlarla ilgilidir, ancak onları insanların genelini ilgilendiren örnekler olarak da görebiliriz (Norman, 2004, s. 158). Sanatın benzersiz değeri, bu şekilde deneyim göstermeleridir. Hayatımızı anlamamıza yardımcı olmak için geniş çeşitlilikte hikâyelere ihtiyacımız varken, dindarlar kendi hikâyeleri grubuna mantıksız bir tercihte bulunurlar. Norman'ın anlayışına birçok noktadan katılmak mümkün olmakla birlikte, muhtemelen anlam arayışı herhangi bir kurgu biçimi tarafından yerine getirilebilir. Okuyucunun aktivitesine hümanist bir çağrı diyebiliriz, ancak bu yaklaşım hümanist bir romanı tanımlamak için bir kriter sunmayacaktır. Sanatın benzersiz değeri, bu şekilde deneyim göstermeleridir. Hayatımızı anlamamıza yardımcı olmak için geniş çeşitlilikte hikâyelere ihtiyacımız varken, dindarlar kendi hikâyeleri grubuna mantıksız bir tercihte bulunurlar. Norman'ın yaklaşımına kısmen katılmakla birlikte, muhtemelen anlam arayışı herhangi bir kurgu biçimi tarafından da yerine getirilebilir. Okuyucunun aktivitesine hümanist bir çağrı diyebiliriz, ancak bu yaklaşım hümanist bir romanı tanımlamak için yeterli bir veri sağlamaz.

Dinin toplumda oynadığı rolün bir sonucu olarak ortaya çıkan istikrar, güven ortamı ve rasyonel atmosfer, on sekizinci yüzyılın başında insanlar seküler dünyanın tam olarak gerçekleştirilmesine gayret 
ettiler. Bundan dolayı seküler bir tür olarak romanın bu dönemde ortaya çlkışı tesadüf eseri değildir. Ian Watt, eski romans geleneğine karşın, sıradan insanların sıradan yaşamlarının romanda yer bulması, karakterlerin adları soyadları ile diğer kişilik özellikleri ve karakteristik özellikleri ile bireysel deneyimin romanın temelini oluşturması Aydınlanmanın temel öncülleri ile paralellik göstermiştir. Bu açıdan Watt'a göre "roman, entelektüel odak noktasının evrensel nitelikte olduğu iddiasına dayanan klasik ve ortaçağ mirasıyla bağlarını kopardığı modern bir çağda ortaya çıkmıştır” (Watt, 1957, s. 244).

Hümanizm romanda sıklıkla ifade alanı bulmuş olması, bunun bir tesadüf eseri olmadığını göstermektedir. Örneğin D.H. Lawrence "Morality and The Novel" başlıklı makalesinde felsefe, din ile bilimin her üçünün kendi sabit hakikat anlayışları doğrultusunda insanları belirli bir yönde ve amaç doğrultusunda şekillendirmeye çalıştıklarını belirtir. Buna göre felsefe sabit bir hakikat anlayışını içeren bir düşünceye insanı bağlamaya çalışır. Din, insanı Tanrı'ya bağlamayı amaçlar; bilim ise bu amacını belirli sabit kanunlarla gerçekleştirmeye çalışır. Ancak romanı bütün bu peşin doğrular olan sabitelerden özgür bir şekilde kendi iç tutarlılı̆̆ı doğrultusunda insana kendi hakikatini dayatmak yerine ona hakikati keşfetmesi için bir bağlam sunar. Bu bağlam her şeyin kendi zamanı, mekânı ve şartları ve dinamikleri içinde doğru ve hakikat olduğunu ifade eder. Her şeyi somanda dile getirmek veya o düşüncedeki değişmez gerçekler olarak düşünmek somana iki türlü olası zarar verme potansiyeli taşır: Ya romanı öldürmüş olacağız veya roman kaçıp gidecektir. Roman bize insan ilişkileri aracılığıyla denilen gerçeklik anlayışının mükemmel bir bağlamını olanaklı kılmaktadır. D.H. Lawrence romanı hümanizmin merkezine yerleştirir. George Orwell ise daha tarihsel bir bağlamda da olsa romanı aynı eksende görür. Orwell "Inside the Whale" (1940) başlıklı yazısında:

Bildiğimiz şekliyle edebiyatın zihinsel bir dürüstlük ve minimum düzeyde bir sansür gerektiren bireysel bir girişim ve faaliyet olduğunu belirten Orwell, düzyazının bu konuda şiirden daha önde olduğunu belirtir. Belirli gerçekliklerin ve sabitelerin düzyazıya zarar verdiğini ve romana yıkıcı etkilerde bulunduğunu romanın bütün edebi türler içinde en anarşist olanı olduğunu öne sürer. Din ile roman arasındaki ilişkinin olumsuz olduğunu ima eden şöyle bir soru sorar: "Katolik Kilisesi mensupları arasında kaç tane iyi roman yazarı var? Bir elin parmaklarını geçmeyen isimler ise, kötü Katolikler olarak ün salmışlardır.” Orwell Katolik veya genel anlamda dindarların iyi romancı olamadıklarını iyi romancıların da dindar olamadıklarını öne sürer. Orwell dini özgür düşünceyi kısıtladığını düşünür. Roman esasında pratik olarak Protestan karakterde olan sanat biçimidir: Özgür bir zihnin özerk bir bireyin ürünüdür (Orwell, 1957, s. 39).

Orwell ve Lawrence'ın ortak görüşleri, romanın insan ilişkilerine odaklandı̆̆g özellikle yirminci yüzyllsa zihnin karmaşık yapısı ve bilinç altının bireyin davranışlarına olan etkisinin psikanaliz ile daha açı bir şekilde ortaya konması ile psikolojik durumun da bu sürece dahil edildiğini bir ilişkiler ağıyla romanın bireysel bir keşif yolculuğuna dönüşmüş olması ve dolayısıyla genellemelerden uzak olması ve dogmatik formülasyonlara geçit vermemesi. Lawrence'ın ifadesinde yer alan din, felsefe ve bilim ise anlamaktan çok yargı ifade eden kurallara ve kanunlara dayandıkları keşiften çok hazır formüller önerdikleri için edebiyatın ve özelde romanın işleyişinden ve iç dinamiklerinden farklı bir sürece sahiptirler.

Bu durum romanın didaktik olamayacağı anlamına gelmemektedir. Roman didaktik olabilirse de, doğru olmaması gerektiğidir. Çünkü didaktik olduğu ölçüde sıradan bir yargının ifadesi olan bir belgeye dönüşür ki, bu durumda esas amacı olan bütün karmaşıklığıyla yaşamı anlama çabasından uzaklaşmış olur. Roman yazarı kendi karakterlerinin kişiliklerini, çelişkilerini ve birbirleriyle olan ilişkilerini ortaya koyduktan sonra, bir dogmaya, yargıya başvurmadan yorumu okura bırakır. Romanın karakterlerin kendi davranışları iç dünyaları, çelişkileri ve birbirleriyle çekişme halinin ortaya koyduğu karmaşık 
hakikat anlayışı ile hümanizmin; grubun veya zümrenin tekelinde olamayacağı şeklindeki anlayışı birbirlerini desteklemektedir.

\section{Fanon ve hümanizmin eleştirisi}

Öte yandan hümanizmi tehdit eden üç modele ilişkin olarak Said milliyetçilik, aşırı dincilik ve dışlayıcılık konusuna dikkat çeker: Milliyetçilik kendi kötülüklerini görmemekle üstünlük vehmine kapılmayı beraberinde getiren, çeşitli paranoyakça doktrinlere sahip veya kimii zaman bunları icat etmeye varan, 'bizim' doğal üstünlüğümüze dayanan ve yıkıcı sonuçlara da zemin hazırlayan bir modelin adı olmaktadır. Milliyetçilik ulus üstünlüğüne ve farklı bir ulus olduğuna yönelik yalnızca istisnacılığın kendini aklayan kötülüklerine değil, aynı zamanda düşmanlar, medeniyetler çatışması ve bizim doğal üstünlüğümüz hakkında aşırı savaşçı bir ruha sahip yurtseverliğin egemenliği ve apayrı bir ülke olma anlatılarına ve kaçınılmaz olarak siyasette dünyanın her tarafına müdahale etme zemini hazırlamaktadır. Savunmacı milliyetçilik olarak hümanizm, ideolojik yırtıcılığın ve utkuculuğun toptan onaylanmasıdır. Sözgelimi, sömürge koşullarında bastırılan dillerle kültürlerin canlandırılması kültürel gelenek ve şanlı atalarla ulusal iddiaların ortaya konulması girişimleri ve yapılan bilimsel araştırmalarda büyük klasiklerin üstünlüğünde ısrar edilmesi mümkündür. Ancak milliyetçiliğin ulusal bağımsızlık kazanmakta başarıya ulaştı̆̆g kültürlerde, özellikle iç savaş ve dinsel sürtüşmeler şekline büründüğünde, aşırı derecede bağnaz yabancı düşmanlığının alevlenmesi tehlikesi söz konusu olmaktadır (Said, 2004, s. 32). Ulusal bilinç, "çok hızlı bir şekilde sosyal ve politik ihtiyaçlar bilincine, yani [gerçek] hümanizm haline dönüşme süreciyle zenginleştirilmeli ve derinleştirilmeli” görüşündedir. "Hümanizm" kelimesinin ne kadar garip olduğu, beyaz adamın yönetimini haklı çıkaran emperyalizmden, narsisist bireycilikten, bölücülükten ve sömürgeci egoizminden arındırıp kullanıma açmıştır (Said, 2012, ss. 268269).

Said, hümanizmin çoğu zaman Batı'nın değerlerini ifade ettiği ve dolayısıyla Batılı olmayan değerleri ve kültürel ürünlerini dışladığı gerekçesiyle; örneğin, bir şeyin sırf bizimkilerden biri değil diye, ya da farklı bir geleneğe ait olduğu veya farklı bir perspektif ve deneyimden geldiği, dolayısıyla farklı çalışma süreçlerinin sonucu olduğu için hümanist açıdan doğası gereği ilginç olmadığı düşüncesini asla kabul etmez. Bizim kültürümüzün, bizim dilimizin, bizim anıtlarımızın erdemlerine yurtseverce övgüler düzmekten ibaret kalan gerçek bir hümanizm olamaz.

Aşırı dincilik bunlar içinde kesin ve peşin hükümlere dayandığı, ifade ve düşünce özgürlüğüne firsat vermediği gerekçesiyle en tehlikeli olmakla ilk sırada yer alır. Doğası gereği, anti-seküler, anti demokratik ve insanlık dışı olarak ilan edilir. Ateşli Dincilik, hümanist girişimleri baltalayan belki de en tehlikeli tehditlerin başında yer alır, çünkü doğası gereği açıkça anti-seküler ve anti-demokratik olup, bir tür politika olarak tektanrıcı formlarıyla da hoş görürüz derecede insanlık -dışı şekillere bürünebilmektedir. Koyu fanatikliklerin hepsi özünde şizofrenik bir halde birbirini besleyen, birbirini taklit ede, birbiriyle savaşan ve -en ciddisi- birbirleri kadar tarih dışı ve hoşgörüsüz olan aynı dünyaya aittir. Dinsel fanatizm meselesine 'bizim dinimiz sizinkinden daha iyidir' tutumuyla yaklaşmanın hiçbir haklı gerekçesi olmaz.

Dışlayıcılık ise geçmişte bazı grupların başarılarını değil, bile bile yalnızca kendini yüceltmeye dayanan bakış açısı. Reddiyecilik derken geçmişe bakıp da başka grupların başarılarını, hatta onların başarılı çehrelerini değil, yalnızca bilebile kendini yücelten, anlatıları gören o daraltıcı bakış açısını kasteder. 
Said'e göre hakkında yapılan bütün tartışmalara karşın sorun hümanizm veya hümanizm kuramında olmayıp, daha çok hümanizmin bizzat tanımına aykırı olarak çeşitli tarihsel yaklaşımlarla ele alınmasındadır. Hümanizm ile yakından ilgili olup yine de ayrı bir terim olarak ele alınan sekülerizm, "kökten dinciliği“ ya da Ortadoğu'daki teokratik devletleri "demokrasi ”den ayırmak için kod sözcük olarak problemli çağrışımlara sahiptir. Eleştirel sekülerizm, sömürgecilik tarihi, emperyalizm tarihi, emperyalizm ve ulusalcılık eleştirisinin daha geniş bir bağlamı içerisinde, "liberal disiplinlerin yenilenişini, böyle bir girişimin öznel bilinciyle birleştirmek için" kutsal hümanist meseleye şekil vererek bu türden ikiliklere karşı koymaya çalışır. Dante'nin İlahi Komedya'daki, Auerbach'ın "aşırı öznellik" dediği keşfi sekülerleşmeyi bir kat daha ileri götürmüştür ama insanın öznel bilincine verilen bu önem, dini amaçla bağdaşmaz, çünkü Dante’nin ilk kaygısı kutsal İncil bilgilerini Avrupa edebiyatı olarak bilinen modern bir metin haline getirmekti.

Fanon, Avrupalı için Avrupalı olmayan diğer toplumların, dini, dili ve renginin farklı oluşuna aldırış etmeksizin genel olarak çarşaflı peçeli kadınlar, palmiyeler, sıcak ve nemli aynı zamanda toz-toprakla karışık bunaltıcı bir hava ve develerden oluşan bir çerçevede ele alındığını düşünür. Avrupalıların söz konusu insanlara vahşi bir katil teşhisi koyduklarını belirtir ve buna dair gerçek, çarpıcı bir psikiyatrik analiz örneğini aktarır:

Bu ilkellik sadece özel bir yetiştirmenin sonucu olarak ortaya çıkan bir yaşam biçimi değildir, çok daha derin kökleri vardır. Dayanağını, arkitektonik yapının belirli bir yatkınlı̆̆ından hiç değilse sinir merkezlerinin dinamik hiyerarşik ilişkisinden almış olabileceğini dahi düşünmekteyiz. Bilimsel olarak açıklanabilecek tutarlı bir davranışlar kümesi ve tutarlı bir yaşam ile karşı karşıya bulunuyoruz. Cezayirlinin korteksi yoktur, ya da daha kesin konuşursak, aşağı omurgalılar gibi ara beyin tarafından yönetilir. Korteks işlevleri eğer varsa dahi son derece zayıftır ve fiilen varlığın dinamiğiyle birleşmez (Fanon, 1963, s.301).

Bununla birlikte Fanon için asıl önemli nokta, sadece Freud'u değil fakat Avrupa biliminin bütün bilimsel başarılarını sömürgecilik pratiğine genişlettiğiniz zaman, Avrupa'nın yerli karşısındaki artık normatif bir konum işgal edemeyecek hale gelmesidir. Bu nedenle, Fanon:

\begin{abstract}
İnsanlıktan söz etmeyi sürdürerek bulduğu her yerde kendi sokaklarının her bir köşesinde, dünyanın bütün köşe başlarında insanları katleden bu Avrupa'yı bırakalım... Avrupa dünyanın liderliğini şevkle, sinizmle ve şiddetle ele geçirdi. Bakın saraylarının gölgesi nasıl da gittikçe yayılıyor. Her hareketi mfekanın ve düşüncenin sınırlarını parçaladı. Avrupa, bütün alçakgönüllülük ve tevazu duygusunu reddetti; fakat aynı zamanda her türlü ihtimam ve şefkat duygusuna da karşı çıtı. Avrupa'nın tekniğinde ve tarzında insanlığı aradığımda yalnızca insanın sürekli bir yadsınmasını ve çı̆̆ gibi cinayetleri görüyorum (Fanon, 1963, ss. ?).
\end{abstract}

O halde hiç de şaşırtıcı olmayan bir şekilde Fanon kendi yazı tarzı ve kimi muhakeme biçimleri ona dayandığı halde Avrupa modelini tümüyle reddetmektedir. Onun yerine, “Avrupa'nın muzaffer doğuşunu sağlayamadığı yeni insanı” yaratmanın yeni yollarını bulmak üzere bütün insanları birlikte çalışmaya davet etmektedir (Fanon, 1963, ss. 311-312-313).

$\mathrm{Bu}$ sorunlu ve utanç verici alanlardan kaçınmak için, kültürel formalizmin "insancıl" sonuçlarını en genel şekilde tanımlamaya zorlanır: "Edebiyat çalışması, insanlara olan ilgileri, ilgileri, temaları ve sosyal organizasyonları ile ilgilidir. Edebiyat ve edebiyat eleştirisi ile ilgili olarak, hümanistler, insanlar ve onların etkinlikleri arasında, edebi karakterlerle bağlamsal durumları arasındaki diyalektiği ele almak zorundadırlar." (Miller, 1981, ss. 34-35).

İnsani bilimlerin tarihteki varlığı söz konusu olduğunda, iki zıt görüş ortaya çıkmaktadır: Birincisi, geçmişin özünde tamamlanmış bir tarih olarak görüldüğü, diğeri ise tarihi hatta bütün geçmişi, hala bir 
çözüme kavuşturulmamış, hala yapılanmakta olan, yeni şekillenen, başkaldırıcı, karşılıksız ve keşfedilmemiş alanların varlığına ve buralardan gelen meydan okumalara açık bir olgu olarak görür. Burada değişmez bir şekilde Batı kanonunun üstün olduğu, diğer kültürlerin ve bu kültürlerin ürünlerinin Batınınkilerden mutlak olarak aşağı olduğu tezi artık özellikle ikinci dünya savaşından sonra etkisi gittikçe daha fazla yayılan bir postkolonyal akımla sorgulanmaya başlanmıştır. Bu konuda Avrupa zihninin ve Batı kanonunun da pekala sorgulanması gerektiğini gözler önüne sermektedir.

Avrupa merkezciliğin yanıltıcı biçimde saptırılmış tarih yazımı, evrenselciliğinin taşralılığı, Batı medeniyeti hakkındaki irdelenip süzgeçten geçirilmemiş varsayımları, Oryantalizmi ve tek yönlü ilerleme teorisi dayatma doğrultusundaki girişimleri; bütüncü kapsayıcılıkla gerçekten kozmopolit ya da enternasyonalist bir perspektif ortaya koyma, entelektüel merakı genişletme ihtimali bir yana, bu ihtimali tamamen azaltmaktan başka bir yere varamayacaktır.

\section{Hümanizmin Avrupa merkezci bir dışlamayla Avrupalı olmayanların Avrupa dışında tutulması amacını gizlediği bir söylem}

Avrupa dillerinde yazılmış azınlık edebiyatlarının ve eleştirilerinin üretimine aracılık eden Batı akademik kurumları, hegemonik sürecin bilinçli bir şekilde Üçüncü Dünya entelektüelini dâhil etmeye ve herhangi bir muhalif tutumun ve yabancılaşmanın eğilimin bilinçli bir şekilde kaldırılmasını amaçlayan bağlamı sağlar. Bu Batı Hümanizminin, ister sıkı bir şekilde tanımlanmış isterse gevşek bir şekilde bir dizi değer ve varsayım kümesi olarak düzenlenmiş olsun, Dünya kültürlerinin geleneksel dünya görüşlerinden daha üstün evrensel bir felsefe olarak sunulması yoluyla gerçekleştirilir. Dolayısıyla, söylemsel ideoloji alanında (daha maddi ve somut sıradan uygulamalar tarafindan oluşturulan pratik bilinç yerine) hümanizm, şekillendirdiği üniversite kurumunun evrensel karakteri ve seküler sosyal bilimler kuramının seküler yapısı ile hegemonik kontrole etkili bir şekilde aracılık eder (JanMohamed, 1984, s. 282).

Bununla birlikte, Batı'nın geniş ve işbirliğine dayanan hegemonyası göz önüne alındığında, bu kültürler er ya da geç, tamamen Batı kültürüne teslim olma ihtimaliyle karşı karşıya kalacaktır. Üçüncü dünya halkları, teorik olarak "hümanizminin" eşitliği ve yönlerini sunan, emülasyon için modeller olarak pratikte eşitliği reddeden ve "medenileşmiş" hümanizme erişimini engelleyen ayrı eğitim, ekonomik dışlanma gibi nedenlerden ötürü tarihsel ırkçı hegemonya içinde asimile edilmektedirler. Bu ve benzeri “ikili bağlar" sayesinde Batılı toplumlar, etnik azınlıkları ve Üçüncü Dünya toplumlarını hegemonya içinde alt sınıflar olarak "dâhil etmeyi" "tutmayı" amaçlarlar.

Eleştirmenlerin özellikle azınlık eleştirmenlerinin yakalandığı temel çelişki ve bunlarla tekrar tekrar mücadele etmek zorunda kaldıkları antagonistik tarihsel baskılar: Bir yandan, çoğunluğun kültürüne ve onun baskılarına karşı etnik ve kültürel benzersizliğini tanımlama arzusu var. Öte yandan, aynı derecede güçlü, daha güçlü olmasa da, liberal hümanist kültürün hegemonik baskılarına uymak için bu benzersizliği terk etme çağrısı (Jan Mohamed, 1984, s.289).

Hümanizmin insanı odak noktasına yerleştiren temel ilkesinin epistemolojik sonuçları olmuş ve netice Avrupamerkezci, insanı referans alan bir bilim anlayışının öncülüğünü yapan sosyal bilimler alanının ortaya çıkmasına yol açmıştır. Imannuel Wallerstein modern insani bilimler de denilebilen sosyal bilimler konusunda şu tespitlerde bulunur:

Sosyal bilim tarih içinde Avrupa'nın bütün dünya sistemine egemen olduğu bir noktada Avrupa'nın çözemediği sorunlara bir karşılık olarak ortaya çıkmıştır. Avrupa'nın bu süreçte, içinden doğduğu 


\begin{abstract}
kabın kısıtlamalarının hepsini yansıtan sosyal bilimleri seçmesi, onları teorileştirmesi, metodolojisini ve epistemolojisini kurması fiilen kaçınılmaz bir durumdu. Bununla beraber, 1945'ten sonraki dönemde Asya'nın ve Afrika'nın sömürgecilik zincirlerinden kurtulması ve bunun yanı sıra her yerdeki Avrupalı olmayan dünyanın siyasal bilincinin keskin biçimde vurgulanması, dünya sisteminin politikasını olduğu kadar bilgi dünyasını da etkilemiştir. Bugün, daha doğrusu en azından otuz küsur yıldır bu kapsamda gözlenen önemli bir farklılık sosyal bilimlerdeki Avrupamerkezcilik’in saldırı altında olması, şiddetli ve yoğun saldırılara uğramasıdır. Saldırılar elbette temelde haklıdır ve çağdaş dünya analizleriyle çağdaş dünyanın sorunlarıyla başa çıkma becerilerini çarpıtıp olumsuz yönde etkileyen Avrupa merkezci mirası aşmamız gerektiği ortadadır (Wallerstein, 1997, ss. 21-22).
\end{abstract}

Avrupa'nın, Kilisenin ve Hıristiyanlığın öğretisini reddetmesi, hümanizmi ve hümanist seküler eksenli bilimi temel bir değer olarak kabul etmesi, bir çok konuda elini güçlendirse de söz konusu öğretilerin reddedilmesinin meydana getirdiği boşluğun da kimi sorunları beraberinde getirmesi kaçınılmaz olmuştur. Sosyal bilimlerin bu boşluğu doldurmaya aday bir çözüm pratiği oluşunun yanı sıra, Avrupamerkezci bir karakter kazanması ve siyasal alanlarda da dünya sistemini şekillendirme potansiyelini kazanması da bir başka önemli özelliğini oluşturmaktadır. Daha çok Batılı toplumların sorunlarıyla ilgili olması, Avrupalı olmayan toplumların da sosyal bilimlere yönelmesinde, en azından taklit düzeyinde ilgi duymasında etkili olmuştur. Ancak, her iki toplumun farklı tarihi arka plana, kültürel dokuya ve kendilerine özgü iç işleyişe sahip olması ve belki de en önemlisi, Batı dışı toplumlarda çeşitli düzeylerde tartışılsa da din olgusunun, toplumda hala yerleşik bir değerler manzumesine sahip olması gibi farklılıkların varlığı, bu toplumlarda Batı karakterli sosyal bilimlerin aşılması gereğini ortaya koymuştur. Bu nedenle sosyal bilimler, kısmen de Batı dışı toplumlara yönelik manipülatif önermeleri ima ettiği için saldırıların hedefi olmuş ve farklı bakış açılarının geliştirilmesine zemin hazırlamıştır.

\title{
George Eliot'in Middlemarch ve Silas Marner adlı romanlarında seküler bir din olarak hümanizm
}

Hümanist ve ateist olan George Eliot'ın kişiliği ve romanlarında dile getirdiği düşünceleri çeşitli tartışmaları beraberinde getirmiştir. Eliot'un dine inancı nedir? Eliot'un dini fikri neden bu kadar karmaşık? Dine karşı nasıl bu kadar kararsız bir tutum geliştirdi? Örneğin Martin J. Svalgic'e göre Eliot "İlk sırada yer alan İngiliz romancılardan biri olan George Eliot, en paradoksal olanıdır da. Dinin insan yaşamındaki önemini takdir eder ve onu uygulamak için romanlar yazar; ama Tanrıya inanmaz" (Svalgic, 1965, 285-86). Ancak Svalgic'in bu düşüncesinde bir isabet bulunmamaktadır. Zira Eliot'ın özellikle örgütlü ve kurumsal din anlayışının dışında dünyevi adanmışlıkların ve ahlakın insanları kurtaracağı bir alternatif bir sistem arayışında olmuştur. Genel olarak, George Eliot'un din ile ilişkisi konusunda iki karşıt görüş bulunmaktadır: Kimi eleştirmenlere Eliot ateist, tanrı inancı olmayan bir insan ve yazardır. Biyografisini kaleme alan WH Mallocb'a göre, Eliot, İngiltere'de ve Avrupa'da ortaya çıkan ilk büyük ateist roman yazarıdır kurgu yazarıdır. Bu ifade, Viktorya döneminde birçok eleştirmen ve okuru şok etmiştir. Diğer eleştirmenler ise Eliot'un gerçek hayatından ve romanlarından gösterilebilecek bir ateist olmadığını iddia ediyorlar. George Eliot'un geleneksel Hristiyanlığa meydan okuduğunu iddia etseler de onun hiçbir zaman dini tamamen terk etmediğini düşünürler. Otobiyografiye göre, Eliot hayatının son döneminde kiliseye geri döndü; ayrıca, yirmi yaşında genç bir adam olan John Cross ile evlendi. Eleştirmenlerin bu değişimin nedenlerini anlamakta son derece zorlanmışlardır. Ancak bunun nedenlerini anlaması güçtür. Ancak Eliot'ın kardeşi Isaac'in resmi bir mektubu yirmi beş yıllık sessizliğini bozmuştur. Isaac, evliliğinden dolayı onu tebrik etmiştir ve bu evlilik Eliot'ın, Isaac'ta büyük bir saygınlık uyandırdığını iddia etmiştir. Eliot'un son evliliği, geleneksel dine ve ahlaka verilen bir uzlaşma olarak kabul edilir. (Zhang \& Zeng, 2013, ss. 446-447) Silas Marner Hıristiyanlıktan çıktıktan sonra bir daha ziyaret etmediği Kiliseye kızının evlilik töreni için gitmesi onun Tanrı'ya olan inancından değil de bir ahlaki zorunluluktan dolayı orada bulunduğu anlamına 
gelmektedir. Bu durumu özellikle Nietszche George Eliot'ın tutarsız davrandığını iddia ederek onun ateizmi benimsemesi nedeniyle Hristiyan Tanrı'dan kurtulduğunu ancak Hıristiyan ahlakına sarılmak zorunda olduğunu belirtir. Nietzsche, alaycı bir tonda ve yüzeysel bir eleştiride, aslında dini bilinçdışı kavramı fikrini ima eder ve örtük olarak etik ve metafizik arasındaki ilişkiyi gösterir. Hristiyanlık, tutarlı bir şekilde düşünülmüş ve şeylerin eksiksiz bir görüşü olan bir sistemdir. Kişi bu temel fikirden koparsa, Tanrı'ya olan inanç, bu yüzden parçalara bölünür: Elde kalan hiçbir sonuç yoktur (Nietzsche, 1990, ss.80-81).

George Eliot'ın yaklaşımı ve felsefesi 'liberal hümanist ateizm' ve 'ateist etik hümanizm' olarak nitelendirilmiştir (Dolin, 2005, s. 188). Karakterlerinin gerçekçi bir şekilde dindar olarak temsil edilme biçimi, onun gerçekçi roman kuramına bağlı sanat anlayışından ileri gelmektedir. Eliot'ın eleştirmenlerinden olan Dolin, Eliot'un bütün düşüncesinin, Hristiyanlı̆̆ reddetmek veya kimi rahatsızlıklara neden olan modern gerçekliklerle uyumlu bir hale getirmek değil, onu geliştirmek, anakronizmden korumak ve evrenselliğini ve kalıcılığını güvence altına almak olduğunu ileri sürer. Bu düşüncesini Eliot'ın kaleme aldığı bir mektuptan yaptığı alıntıyla destekler. Buna göre, Eliot için dinin asıl görevi insanların kişisel acılarını yatıştırmak, onlara teselli vermekten çok, insanlığın en zorlu sorunu olan insanlara sorumluluk bilincini aşllamak olduğunu belirtir. (Dolin, 2005, s. 172). Dolin'in düşüncesine iki açıdan itiraz edilebilir. Birincisi, Eliot'ın dini geliştirmek düşüncesi, içerikten bağımsız olarak ele alınamayacağı için bu gelişimin niteliği ve seyrinin doğası daha önemli hale gelmektedir. Dini geliştirmek adı altında acaba dini tümüyle kaldırmak amacını mı taşımakta yoksa dinin kendi iç dinamiğini işlevsiz halef getirerek, onun içini boşaltarak sembolik ve hiçbir yaptırımı olmayan dolayısıyla insanlar için bir anlam ifade etmeyen arkaik bir ideoloji haline mi getirmektedir? Bir diğer itiraz noktası, dinin geliştirilmesine gereksinim var mı? Varsa bu gereksinim kimden gelmektedir? Bilindiği üzere Eliot erken yaşlarda, Ludwig Feurbach'ın Essence of Christianity adlı eserini İngilizceye çevirmiş ve bu eserden ne ölçüde etkilendiğini ifade ederken, herhangi bir yazarla ilgili çok ender olarak kullandığı bir ifadeyi Feuerbach için sarfeder "Feuerbach'ın fikirleriyle her yerde aynı düşüncedeyim" der (Haight, 1954, s. 153). Bu eserinde, Feuerbach, humanizm merkezli dininin "gerçek ya da antropolojik özü", tüm dini ritüellerin insanın doğuştan getirdiği ve doğa güçlerine duyduğu sempatinin yarı bilinçli bir ifadesi olduğunu vurgular. Dolayısıyla Eliot'ın da anlayışının bu düşüncenin etkisinde ve gerek mektuplarında gerekse Adam Bede, Silas Marner gibi eserlerinde bariz bir şekilde görüldüğü üzere, 'hümanist din' anlayışıyla nitelenebilecek bir çerçevede olduğu değerlendirilebilir. Dolayısıyla Eliot hem atesit bir insan, yazar ve filozof olarak hem de dinin toplumdan dışlanması gerektiği yönündeki çıkarımlarla, dinin geliştirilmesi değil tedavülden kaldırılması sonucuna ulaştığı anlaşılmaktadır. Öte yandan, Felicia Bonaparte, "Bana göre, düşüncesinin tek temeli olarak ampirizmden memnun kalmamış, ancak teolojik bir inanca geri dönmeyi istemeyen Eliot, kendisi ve modern dünya için seküler fakt aşkın bir din arayışına girdi." (Bonaparte, 1991, s. 39)

1859'da türlerin kökeni adlı eserin yayınlanmasıyla birlikte, Charles Darwin’in fikirleri, Hıristiyanlık doktrinine ciddi eleştiriler getirdi. John Stuart Mill'in ampirik bilgi kuramı olarak ifadesini bulan The System of Logic (1843), The Principles of Political Economy (1848), On Liberty (1859), Utilitarianizm (1863) ve Autobiography (1873) gibi başlıca eserleri evrim teorisinin etkisinde dogmatik düşünce tarzlarına ve doktriner sistemlere karşı geliştirilen ve kuşkuculuğu yayan yeni yaklaşımlar ortaya çıtı. Diğer taraftan, Auguste Comte'nin pozitivist felsefesi İngiltere'de etkili olmaya başlamasıyla, dinin etkisinin giderek azalması ve yerini hümanizme bırakmasına yol açtı. Bu durum Herbert Spencer'ın sentetik felsefesinin 1860'lardan itibaren evrim düşüncesinin uzamını biyolojiden psikolojiye kadar birçok alanı kapsayacak şekilde genişletti. Fakat aynı zamanda bilimin alanını aşan kimi "bilinemez" konuların varlığını da yadsımadı. Agnostisizm ve etik konusunda ortaya çıkan yeni akımların da etkisiyle 
1860'lar ve sonrasındaki bilimsel akımlar, 19. Yüzyıl İngiltere'sinde yeni nesil roman yazarlarını etkisi altına alarak, Hıristiyanlığa karşı daha sorgulayıcı ve dini öğretilere karşı daha eleştirel bir tutumun ortaya çıkmasını sağlamışlardır. Ludwig Feuerbach’tan etkilenen George Eliot, onun Tanrı yerine sevgiyi ikame eden hümanist felsefesini benimser. Eliot, insanları yardım eden bir Tanrı düşüncesini terk ederek, artık insanın insana yardım etmesi gerektiğini ve buna inanmamızın zorunlu olduğu anlayışına ulaşır (Faulkner, 1975, s. 43). Eliot'ın kitapları genel olarak aynı sonuçta birleşirler: İnsanın dünyadaki varlığı dış veya İlahi müdahalelerden uzak bir şekilde insan ile ve insanın sayesinde anlam bulur. İnsanın toplumsal ve ahlaki gelişimi, insanın dışındaki bir başka varlığa, güce otoriteye bağl değildir. Anna Neill, bilim ve din arasındaki ilişkiyi araştırdığı ve George Eliot'un yaşamın gizemine inandığını ve birçok eleştirmenin iddia ettiği kadar rasyonalist olmadığını belirtir. Bu nedenle Eliot'ın, Darwin'in 'Türlerin Kökeni'nin açılı̆̆ı ve dürüstlüğünü övgüye değer bulan George Eliot, bu kuram ışığında gelişme teorisi ve olayların ortaya çıkışını ve diğer tüm süreçleri benzer şekilde açılama eğilimindedir (Neill, 2008, 939-940). Tanrı fikri ise bütünüyle insani ve insanın yüceltilmesine dayanır:

"Ve onun dininin anlamı bu: Yüce Tanrı'nın gelmesini istiyor. Bu saçmalık!

Eskiden kiliseye gittiğimde açıkça inandığım bir şey vardı: Tanrı Yüce toprağa bağlı. Toprak vaat ediyor, toprak veriyor, mısır ve sığırlarla insanları zengin yapıyor. Ama sen diğer tarafı tutuyorsun." (Eliot, 2000, s. 71)

Middlemarch, Romola ya da Adam Bede'den daha az din ile ilgili görünse de, George Eliot burada, dinin nosyonunu ve pratiğini tanımlamayı amaçladığı için eserde tutarlı bir toplumsal inanç ve düzen bulunmamaktadır.

Eliot insanın yüceltilmesi ile Tanrı'nın egemenliğinin esas olarak dünyada söz konusu olduğunu, öte dünyayı reddetmemekle birlikte, Tanrı'nın varlığının insanlar için bu dünyayı anlamlandırdığı düşüncesindedir. Sıradan insan hayatının dışında duran bir güç olmaktan ziyade, din bir bütün olarak görülmelidir. Dini kaygılar, kişisel ve sosyal kaygılarla bütünleşik ve dürüstlük arayışıyla bağlantılı olarak görülmelidir. George Eliot'un Dorothea karakteriyle Theresa'yı yeniden anımsatması, yaşamının ilerleyen yıllarında öne çıkan çeşitli maneviyatı romanının önemli bir unsur haline getirmesiyle birlikte, bu dönemde aynı zamanda eski mistik geleneklere olan ilgisinin de başladığını gösteriyor. Romanda kahramanın kendisini içinde bulduğu çıkmaz, modern insanın içine düştüğü kriz anlamına gelmektedir. İnanç krizinde, o da aşkın bir şekilde inançtan yoksun kalmıştır. Tıpkı Hz. Adem gibi, o da zamanın cennetten, kendisini mutlu ve güvende hissettiği bu dünyadan inancını yitirdikten sonra evsiz bir sürgün olmuştur.Bu nedenle modern insanın öyküsü seküler bir anlatıda hayat bulur. Eliot'un anladığı gibi, seküler bir çağda, ruhsal romantizm azalmış ve kaybolmuştu ve dünya sonunda ruhsal köklerini yitirmişti. Bundan geriye kalan ve inançtan yoksun olan bu dünyada Eliot'un yapmak istediği tek şey ahlaki çıkış noktası bulmaktır.

Middlemarch'ta, Eliot sadece katı alegorik okumaları reddetmez aynı zamanda, teolojik bir gerçeği ortaya çıkarmak için, seküler bir çağda sadece ampirik gerçeği algılayan katı edebi okuma türünü de reddeder. Ne teoloji ne de bilim, modern inanç krizine cevap değildir. Bununla birlikte, bu diyalektiğin bir çözümü vardır ve Eliot bunu Ladyslaw'da, Dionysos'un mitolojik figürünü içerdiği Ladislaw'da sunar.

Eliot, Evanjelik Hıristiyanlığı terkederken, tam ve tutarlı bir hümanizme ulaşır. Buna karşın, radikal bir seküler olmadığı gibi, kilise müdavimlerine ve onlardan biri olan babasına müdahale etmemiş, Comte'nin 'hümanist dini'ni benimsemekle yetinmiştir. 1850'de Cenevre'de, her ne kadar dini inancını yitirmişse de dini duygulara düşman değildir. Aradan geçen on ylllık bir deneyimin kendisine öğrettiği 
bir kazanım vardır: İnsanın, teselli bulmak için sığındığı veya özlemini duyduğu her hangi bir dini veya manevi duyguya kin duymamaktadır. Tam aksine, Eliot kendi diniyle de barışık olmadığı ve ona karşı olduğu için mutsuzdur. Bu sürede iç dünyasında büyük değişimler geçirmiş, sonuçta, her dine bütün tartışmaların üzerinde sempati duymaya başlamıştır. Eliot, Hıristiyanlı̆̆a bir daha dönmemiş doktrinine inanamamış ve görünmeyen ve insanüstü bir vahiy olgusuna inanamamakla birlikte, din gerçeğinin insanlık tarihinin en önemli konumunu işgal ettiğini düşünür ve her çağda samimi Hıristiyanların içsel yaşam deneyimine kendisini daima yakın hissettiğini anlamıştır. Hıristiyanlıktan kopuşunun bir başka etkisini ise, belirli konularda eskisinden daha az kendisinden emindir. Eliot önceleri, dini inancını yitirdiği dönemlerin başlarında, kendisi gibi düşünenlerin nicelik olarak daha az olduğunu bunun da kendisine farklı ve ayrıcalıklı kıldığını düşünerek bunun konforunu yaşar. Ancak ilerleyen dönemlerde duygusal olarak farklılıktan çok yakınlık ve hemfikir olma noktasındadır. Gerçek varlığımızın durumuna gelince, varlığımız bu dünyevi varlıktan ibarettir ve bu dünyadaki mücadelemize bağlı olarak şekilleneceğini düşünür (Faulkner, 1975, s. 47).

Eliot, din konusunda karşı olmaktan çok agnostik fakat duygusal olarak dindar ve inançlı insanlara yakınlık duyar. Bu durum ingiltere'de alışılmadık bir durum değildir: Çünkü Hıristiyanlığın birden fazla yorumu olduğu gibi, Hıristiyanlığa mensup insanların da bireysel, kültürel, politik sosyo-kültürel farklılıkları göz önünde bulundurulduğunda nedeni daha açık bir şekilde ortaya çıkar. Eliot, dini; dünyevi ve insani ilişkilere indirgemekle, İlahi kaynaklı yardım, müdahale gibi yaklaşımların yerine insanın kendisine ve yeteneklerine güvenmesini, böylece bu dünyayı yardımlaşarak yaşanır bir hale getirmeyi amaçlar. Middlemarch'da Mr Vincy,

"Ben sadece dünyevi olarak kalmaktan başka bir şey düşünemem; ve dahası, dünyevi olmayan hiç bir kimseyi göremiyorum. Sanırım dünya dışı ilkeler dediğiniz şeyle ilgili bir iş yapmıyorsunuz. Gördüğüm tek fark, bir dünyalığın diğerinden biraz daha dürüst olduğudur. " (Eliot, 2000, s.83).

Aynı şekilde insanın daha büyük hedeflere sahip olmadan dini bir yaşam biçimine erişemeyeceğine olan inancını dile getirir (Faulkner, 1975, s. 46). Eliot, din gerçeğini kabul etmekle birlikte, edebiyatın ve dinin; edebi dilin de, din dilinden ayrılması gerektiğini düşünür. Dolayısıyla her iki durumda da dogma olarak nitelediği bu duruma karşı çıkar. Sevgi ve saygı insan ilişkilerinin ve insanın iyi olmasının temel şartıdır. Eliot, karakterlerini farklı, kimi zaman da birbirine tamamen zıt kişilik özelliklerine sahip bireylerden seçerek, toleranslı yargı, açma ve duygusal yakınlık gibi insani duyguları sentezleme amacını gerçekleştirmeye çalışır. Ona göre, eğer sanat, insanın duyarlılığını arttırmaya hizmet etmiyorsa, sanatsal açıdan son derece eksik kalacaktır. Zira insanlar arasındaki ilişkiler söz konusu oluğunda düşüncelerin önemi ve işlevi son derece zayıf kalır. Asıl olan, empati kurmak ve yaşanan olumlu ve olumsuz durumları, acıları, sevinçleri hissetmektir. Çünkü yalnızca trajik ve mutlu yaşantıları konu alan eserler, bizim gerçek yaşantılarımıza ayna tutabilirler. Hayatta üstesinden gelemediğimiz, çözümünde güçlükler yaşadığımız sorunlar olsa da, bunlar Eliot'a göre insanların birbirleriyle dayanışmalarıyla aşlabilir.

\footnotetext{
"Ama benim kendi inancım var ve bu beni rahatlatıyor."

"Nedir o?" dedi Will, daha çok inancı kıskanarak.

"Mükemmel olanı arzulayarak, ne olduğunu tam olarak bilmiyor olsak ve yapmamız gerekeni yapamazsak bile, kötülüğe karşı ilahi gücün bir parçasıyız - ışı̆̆ın alanını genişletmek ve karanlıkla da onu daha da daraltmak için mücadele ederiz.

"Bu güzel bir mistisizmdir" - (Eliot, 2000, s.244)

Daha sonra Dortohea Will'in inancını merak eder:
} 


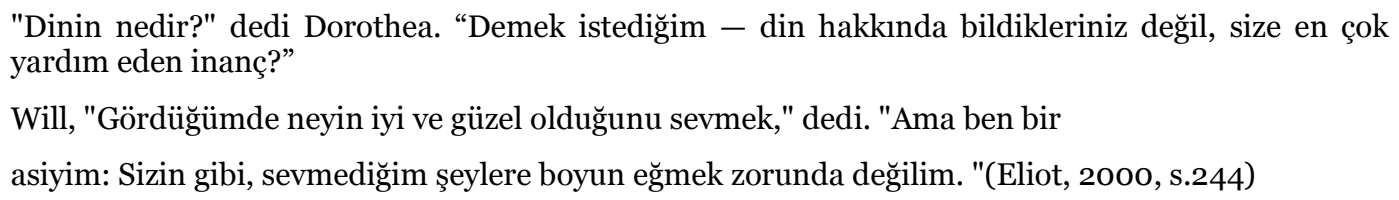

Edebiyat anlatı aracılığıyla başkalarının hayatını hikayeleştirerek anlatırken, okurların bu hikaye ile belirli düzeyde özdeşleşmesini sağlar. Hayatın anlamı, sadece belirli dini veya ideolojik doğruları öğrenmek ve onu kural olarak benimsemek ve uygulamak değil, daha çok anlamayı, özellikle ve öncelikle kendimizi anlamayı gerektirir. Hayatımızı sadece belirli doğrulara göre dizayn etmekten çok, onu doğru bir şekilde anlamaya daha çok gereksinim duyarız. İçinde yaşadığımız dünya ile toplum ve insanlarla kendimiz dışındaki koşulları anlamak için çaba sarf etmeliyiz ki, bu bizim dışımızda bize verilen bir takım hazır çözümlerden daha gerçekçi bir durumdur. Edebiyat, bize sunduğu başka hayatlar aracılığıyla onların deneyimlerini paylaşma değerlendirme ve anlama imkânı sunarak kendi yaşantımız üzerinde yeniden düşünme firsatı sunar. Edebiyat diğer bir açıdan anlatı aracılığıyla dini öğretilerde yer alan hikâyelere ( $k \imath s s a$ ) olan benzerliğiyle de onunla ortak bir paydada yer aldığını gösterir. Anlatı bize yalnızca bir kez deneyimleme olanağı bulduğumuz olayları, bir başka karakterin yaşamında veya deneyiminde gözlemek ve anlamakla, o andan itibaren yönelimlerimizi sorgulama ve hayatımızın sonrasındaki eseri için isabetli karar verme belki de ilerideki olası yanlıştan sakınma firsatı sunabilecektir. Kimi zaman da hayatının bazı dönemlerinde hata yaptığını düşünen insanların "itiraf" veya "denemeler" gibi başlıklarla kaleme aldıkları eserler yine okurlar için önemli kazanımlar içerme potansiyeli taşırlar.

Kendimizi veya başkalarına ait deneyimlerimizi anlatıya dönüştürerek hayatın anlamına dair bir metin haline getirdiğimiz başlıca edebi türler roman ve hikayedir. Hayatın anlamını bize açıklayabilecek bilgi türü, kimi hümanistlere göre ancak bilimsel bilgi olabilir. Bilimsel bilgi, evreni fiziksel dünyamızı olaylar ve olgular arasındaki sebep sonuç ilişkisiyle anlamamızı sağlayan bilimsel bilgidir. Bilimsel bilginin aynı şekilde batıl inançlardan aydınlanmaya geçiş sürecinde oynadığı rolü göz önüne aldığımızda bu durum zihinsel devrimlerin yalnızca görünümlerinden birini oluşturmaktadır. Ancak bilimsel bilginin bütün sorulara yanıt verdiğini düşünmek yanıltıcıdır zira, her soru bilimsel nitelikte değildir.

Söz konusu sorulardan biri, "hayatın anlamı nedir?” sorusudur. Böyle bir sorunun yanıtı ikna edici bir üslup ile bize başkalarının hayat hikayesini paylaşarak kendi deneyimlerimiz ile sentezleyerek yeni bir yaklaşımla anlayabiliriz.

Middlemarch'ın sonunda Lydgate'in inşa etmek istediği hastane projesi yanlış ortak ve yanlış eş seçimi nedeniyle başarısızlığa uğrar. George Eliot, hayatının erken dönemlerinden itibaren Hıristiyanlık'ta dinin doğaüstü ve ilahi kaynaklı karakterini benimsememiş, dolayısıyla hümanist ve rasyonel bir din arayışına girmiştir. Eliot için insanlığın dini, dinin özünün ilahi olandan seküler olana, Tanrı'dan İnsana dönüştürülmesiyle meydan getirilebilecek olan bir yeniliğe gereksinim duymaktadır. Hristiyanlıkla karşılaştırıldığında, Eliot'un insanlık dini bir dinden çok bir tür yaşam tutkusudur: George Eliot dini, doğaüstü karakteristiğinden soyutlayıp Tanrı'yı pratik anlamı olmayan doğaüstü bir güç olarak görmüş ve bundan ötürü eserlerinde eserlerinin özellikle Hıristiyanlığın erken dönemlerinde bulunabilecek anlamlı fikirleri ısrarla seküler bir çerçevede dile getirmeye çalışmıştır. Tartışmalı hümanist statüsüne rağmen Eliot, her türlü samimi dini inançlara büyük saygı duyar. Eliot, geleneksel dinin desteğine ihtiyaç duyanlara sempati duymuştur, çünkü bütün insanların bir aidiyet hissi ve yalnızlık ve hayal kırıklığını terk etmenin bir yolunu bulmak istediklerini düşünmüştür. Eliot, geleneksel dinin gücünün ve değerinin bu ihtiyaçları karşılama yeteneğinde yattığını hissetti. Ancak Eliot, Tanrı'nın 
illüzyonunun yalnızca insanları felç edebileceğini, bunun yerine dünyevi ve seküler bir anlayışla sevgi ve sorumluluk duygusuyla hareket etmenin ilahi kaynaklı dinin yerini alabileceğini, bunun da güven dolu bir toplumda, insanların birbirine güvenerek aidiyet duygusu kazanmasına imkan verdiğini düşünür. Dinin yerine ikame edilen bu hümanist ve seküler din anlayışının görsel Tanrı yerine daha anlamlı olduğunu, yeni anlayışın daha tatmin edici olduğuna inanır. Bu nedenle, Eliot'un insanlık dininin bireyselliği, din ve ahlak konusundaki görüşünün sınırları ilerleyerek nihayetinde ateist, hümanist ve seküler bir din anlayışına ulaşır.

George Eliot'ın Hıristiyanlığı ve dini anlatıyı, seküler bir anlatı olan roman aracılığıyla seküler bir dine tercüme ederek işlediği eseri olan Silas Marner, Eliot'un en olgun eseri, sadece olgun yazma becerisinden dolayı değil, aynı zamanda hikayedeki insanlık dininin mükemmel bir sergisidir. Silas Marner'da sunulan dini ve ahlaki yansımalar, Eliot'un teolojik çalışmasında ve geleneksel inançlara meydan okumada atılım olarak kabul edildi. Adam Bede gibi ilk çalışmalarında, Eliot'un Hristiyanlığa karşı tutumu yarı hiciv, ahlaki standartlarına yarı yarıya yaklaştı. Her ne kadar Eliot Hristiyanlıktaki çeşitli doktrinlere ve ritüellere ilişkin olarak kimi düşüncelerini, Scenes of Clerical Life ve Adam Bede gibi eserlerinde taşlama öğelerinin ağır bastığı bir tonda ele almış olsa da, romanlarında açıç̧a Hristiyanlığa karşı bir tutum takınmaktan kaçınmıştır. Silas Marner'da Eliot ilk kez, Tanrı ile insan arasındaki ilişkiyi ve insanın içine düştüğü kaostan ve büyüsü bozulmuş bir dünyadan nasıl çıkılacağını ve bununla ilgili sorunları tartıştı. Bu yönüyle Silas Marner, Eliot'un Hıristiyanlı̆̆ı açıkça tartışma konusu ettiği ve bu yöndeki düşüncelerini roman aracılı̆̆ıyla okura doğrudan ilettiği ilk eser olma niteliği taşır. Silas Marner'de kahramanın, Ortodoks Hristiyanlıktan bir hümanizm dinine dönüşünü, Eliot'un eski dininden ayrılmak için verdiği kararı ve yeni bir manevi dünya kurmaya çalışmasını dile getirir. Buna göre Eliot, bu eserde hümanizm dininin özünü cesaretle ortaya koymuş - Tanrı yerine insanı, ilahi aşk yerine dünyevi ve seküler bir sevgiyi ikame ederek, insanların umutsuzluk ve çaresizlik içinde kıvranan ruhunu karanlık dünyadan kurtarmaya teşebbüs etmiştir. Anlatısının dili de, elbette ki ilahi vahye dayalı olan kutsal din dili değil, insanoğlunun içinde yaşadığı dünyanın hümanist seküler dili olacaktı.

Silas Marner, din tarafından şekillendirilen bir anlayış ile hümanizmin öngördüğü anlayışın çatışmasında insanın konumunu anlamlandırmaya çalışan bir girişimin romanıdır. Dinin insana yüklediği ve kaynağını Kutsal Kitap’tan alan, insanı Tanrı karşısındaki rolüyle tanımlayan ve bu rolünün gereğini yerine getirirken başta şeytan olmak üzere aklını ve duygularını çelmeye çalışan, her firsatta onu yöneltildiği hedeften saptırmak için var gücüyle tökezletmeye çalışanlara karşı, engelleri aştığı ölçüde takdir ve değer gören bir varlık ile diğer tarafta değerini dışarıdan, ilahi bir otoriteden, kurumdan veya kutsaldan almayan anlamını bizzat kendi varlı̆̆ından alan, değer ölçüsü 'insan' olmaktan ibaret olan bir başka perspektifin karşılaştırılmasıdır. George Eliot'ın bütün çalışmalarında olduğu üzere, küçük hacimli ve yetişkinlerden ziyade çocuklar için kaleme alınan bir eser olduğu düşünülen ve ancak son yirmi yılda ciddi bir ilgiye kavuşmuş olan Silas Marner'da da dini ve manevi arayış ve bunun hümanizm ile olan ilişkisi hatta yer yer çatışması vardır. Yirminci yüzyıla değin, eleştirmenler Silas Marner'ın dini içeriğine daha az ilgi gösterdiler. Kimileri George Eliot'ın agnostizmizmi konusunda israr etti. Ancak roman, II. Dünya Savaşı yılları ve sonrasında, farklı algılamalara konu olmaya başladı. Aralarında Nietzsche'nin bulunduğu bazı önemli eleştirmenler de artık Eliot'ın eserindeki dini temayı görebiliyordu. Nietzsche'nin Eliot hakkındaki bilgisi çok az olmasına rağmen, onun etik anlayışının Hristiyan olduğunu ve bunun da Eliot'ın Hristiyan sayılması yeterli olduğunu anlamıştı. Felicia Bonaparte'ın son derece yerinde tespitiyle "George Eliot, Kitabı Mukaddes'i seküler bir metne tercüme etmektedir." (Bonaparte, 1991, s. 40) 
Eliot için, seküler yaşam, çağdaki yaşam kadar kutsal olabilir. Silas Marner'ın belirli takvimleri ve günleri, gün dönümleri vardır. Eylemlerin çoğu aynı zamanda kış gün dönümü olan Noel'de ve baharın yeniden doğuşu olan Paskalya'da geçer. Bu nedenle, her eylemin gerçekleştiği tarihe göre, sıradan insan yaşamına dini bir önem verilir. Dini takvimler ilerlemeyi sadece dış olaylarla değil ama karakterlerin iç hayatlarıyla da ilişkilendirir. Ancak Godfrey'in davasında, takvim bir semboldür. Birçok kez romanda, Godfrey'e günlük hayatında önemli olayların gerçekleşme durumuna ayrı bir önem atfedilir. Dini gözlemlerin anlamları bulunur. Çocuğunun doğumu, ritüeller, cemaatin kutsallığına dikkat çekilir. Kavramsal seküler bir dilde, roman Mesih'in hikâyesini anlatır. Romandaki Mesih, Eppie'de somutlaştırılmıştır. Böylece Eppie, seküler hümanist bir inancın temsilcisidir. Aynı zamanda ilahi dinlerin kurtarıcı mesajlarını dünyaya ulaştıran meleklerin insani olan görevlisini imgeler. Modern dünyaya getirdiği mesaj ise sevginin hala insanı yücelten bir değer olarak varlığının çok önemli olduğunu bir insanın diliyle ve yaşamıyla anlatmasındandır. Bu yönüyle Hz. İsa'nın yeryüzündeki eşdeğeri ve onun yerine geçen bir değer olarak karşımıza çıkar. Sadece insan soyundan gelen bir 'hümanist' değil getirdiği haber de ilahi olmayıp sekülerdir. Dolayısıyla dünyanın harap olması ve kıyametin kopması insanın bu inancından vazgeçmesinden dolayı değil, bu inancını hümanist ve seküler bir inanç olarak anlayıp öteki inançlarla yollarını ayırması ve yeni bir dünya inşa etmesinden ileri gelmektedir. Eliot, Hristiyanlıkta çok nemli bir yer tutan itiraf konusunu da işler. Burada itirafı iki farklı şekilde kullanılır. Hem dünyada yapıp ettiklerimizin cezai bir karşılığı ve pişmanlık duygusunun kötülükten sonra verdiği maddi ve manevi, vicdani ıstırap duygusunun sezdirilmesi hem de yine bu itiraf ile bu istıraptan kurtulup yeniden kendimizle, dünyamızla birlikte olmanın mutluluğunu tatmamıza firsat veren yeniden doğuşa imkân vermesi yönüyle romanda yer almaktadır. Godfrey'in itirafları bu ikisinin de gerçekleşmesinin bir göstergesidir. Eliot, Silas Marner'in hikayesinde, Kitabı Mukaddes'i edebiyatın bir türü olan romana, din dilini seküler bir dile, Hristiyanlığın kutsal kitabında anlatılan kıssaları mite ve sembollere ve nihayetinde ilahi bir metni seküler bir metne dönüştürmüştür. Eliot'un hümanizmi nostaljik, anakronistik inançlar ve kültürel yönelimlerin, modern ahlaki yıkıma karşı tutulan inanç değildir. Eliot, Hıristiyanlık kültürünü bilimsel bir keşif ilerlemesi çağında yeniden şekillendirme arzusuna sahipti. Ancak, rasyonel incelemeye dayanmayan ilkel Hıristiyan batıl inançlarını atma konusunda, Almanya ve İngiltere'deki ilerici düşünürleri takip etmesine yol açan, ilahi bir doğaüstü varlı̆̆ın varlığı, ruhun ölümsüzlüğü ve Tarihsel İsa'nın Tanrısı'ndan vazgeçmesi ile insani ilerlemeye duyduğu sarsılmaz inancı ve seküler bir sebepten öte bir şey değildir.

Öykü, on dokuzuncu yüzyllın başlarında İngiltere'nin kırsal yörelerinden birinde geçmektedir. Dokumacı Silas'ın on beş yıldır yaşadığı Raveloe köyü, hiçbir şekilde fakir bir köy değildir. Gerçekten de "medeniyetin eteklerinde yatan o kısık kiliselerden biri" değil (5), aksine "Merry England diye adlandırdığımızın zengin merkezi ovasına yerleştirilmiş". (3) Silas Marner, memleketini terk ettikten sonra Raveloe'ye yerleştiğinde, oranı halkı tarafından çok hayal kırıklı̆̆ına uğratıldı ve Tanrı'ya olan inancını yitirdiği zaman "istenmeyen” kişilerden biriydi. Her şeyden önce fiziksel olarak farklıydı. "Kashı kasaba halkı" ile karşılaştırıldığında "solgun cllız" bir adamdı.

Silas Marner, çevresinde iyi dokuma ustası ve dini bütün bir adam olarak Lantern Yard'daki dini cemaatine ve kiliseye bağlı bir adam olarak yaşamaktadır. Tanrı'ya ve Kutsal Ruh'a, kendisini adamış, inancında şüphelere yer olmayan bir insandır. Bir gün en yakın dindaşlarından birinin iftirasına maruz kalan Silas, hem arkadaşlarını, hem nişanlısını hem de inancını yitirerek bulunduğu şehri terk eder. Silas Marner, George Eliot'un genel olarak başka bir realist olarak nitelenen veya onun anladığı anlamda realist romanlarından biridir. , Bu romanında da açıkça efsanevi ve sembolik öğeler bulunmaktadır. 
Silas Marner romanın başlarında önyargı ve ona bağlı olark batıl inançları eleştirerek bulunduğu kasabanın durumunu gözler önüne serer. Anlatıcı, "eski zamanların köylülerinin" sadece gezginleri ve yeni gelenleri değil, aynı zamanda uzun süredir köylerine yerleşmiş olanları da güvensizleştirdiği gerçeğine işaret ettiğinden daha keskin gözlemlerde bulunur. Önyargıları o kadar köklüdür ki, bu kişilerden biri bir tür bilgiye sahip olsa bile, şüpheli görünürdü ve aralarında hayatı boyunca kusursuz bir dürüstlükle yaşamış olsa bile, hala ona güvenmiyorlardı:

"Eski zamanların köylüleri için, kendi tecrübelerinin dışındaki dünya belirsizlik ve gizem bölgesiydi; onların dar görüşlü düşüncelerine göre, bir gezinme durumu, ilkbaharla birlikte gelen kırlangıçların kış hayatı kadar karanlık bir kavramdı(...) ve uzak bir bölgeden gelmiş olan veya bir yerleşimci bile,(...) güvensizlikle görülmekten neredeyse hiç kurtulamazdı; bilhassa bilgi için herhangi bir üne sahipse veya el sanatında herhangi bir beceri göstermişse" (Eliot, 1996, ss. 3-4).

Bu köylüler önyargılıydı, çünkü başka bir dünyanın veya kendileri dışında başka insanların varlığından habersiz yaşıyorlardı. Yabancılara karşı önyargılar bir dereceye kadar anlaşlabilir olmakla birlikte kendileri gibi yerleşimci olanlara karşı olan tutumları anlaşılır gibi değildi. Bu sakinler de sonradan yerleşenler oldukları için hala kendilerinden sayılmamaktadırlar. Nedeni ise sadece bu kişi aslında başka bir bölgeden olduğu için. Ön yargılarının ya da güvensizliğinin diğer bir nedeni de kişinin "bilgisi" idi. Bu "göçmen" onlardan daha iyi konuşacak olursa, daha becerikli ise, bu da kendisinden şüphe duyulması için yeter sebepti. Sıradanlığın ötesindeki akla güvenilmezdi. Köylülerin başkalarını tanıma ve anlama çabasına girmeden yargılamaları onların kendilerindeki kibir duygusunun bir yansımasının göstergesidir. Bilgiye ve bilmeye önem vermeyen toplumların tipik bir karakteristiği olan kibir, ancak doğru bir bilgilenme ile aşllabilir ve alçakgönüllüğe kanalize olabilir. Ve kendilerinin dürüst olduğunu dolayısıyla karşılarındaki yabancının bu nitelikten yoksun olduklarını düşünmeleri de yine bilgisizliklerinin bir başka görünümüdür. Her iki durumda da cehaletten kaynaklanan yersiz bir özgüven ve kibir ile kendilerini doğru ve dürüst bir şekilde değerlendirme ve özeleştiri mekanizmasından yoksun olan bu insanların, bilgi artıkça tevazu artar kaidesinin tersinden okunmasıyla cehalet arttıkça kibir ve ön yargıların da o denli arttığı bir olgu ile karşı karşıyayız. Çocukların birbirlerine Silas hakkında söyledikleri aslında ebeveynlerinden duyduklarını taklit etmektir. Buradaki anlatı, köylülerin bir şekilde Kutsal Kitap'la bağlantılı ve kaynağını oradan alan bir şeytan algısını ifade eder.

Eliot, Silas Marner'da dinin niteliği ve işlevi üzerine düşüncelerini en açık şekilde dile getirdiği paragraflardan birinde dinin daima görünmezlik niteliği ve gölgeli bir güç anlayışıyla, sahip olduğu gücün insanlara zarar vermemesi, onları ürkütmemesi için üstü örtülü biçimde gizemli bir yapıda sunulduğunu iddia eder. Görünmezlik niteliği sayesinde din aynı zamanda her insanın zihninde en kolay şekillenen bir olgudur. Zorlu işler hiçbir zaman hevesli bir dini inançla aydınlatılmamıştır. Din mutluluk, eğlence ve hayal gücünden çok daha fazla acı ve talihsizlik yelpazesi sunar (Eliot, Silas Marner, 4-5).

Bu ifadeden de anlaşılacağı üzere yazarın dine karşı tutumu bariz bir şekilde ortaya konmaktadır. Dini inanca konu olan varlıkların duyu organlarımızla algılanmaması, dinin barındırdığı gücün sır perdesine bürünmesi ve insanların zihinlerinde herkes tarafından kendi dünyasında istendik şekli almasını beraberinde getirdiği gibi, bunun insanların zihinlerini şekillendiren kişi ve otoritelerin elinde bir istismar aracı olarak kullanılmaya açık olduğunu da ima eder. Bu durum en çok görünmez olan Tanrı konusunda ileri sürülebilecek düşünceler için geçerlidir. Bununla birlikte, köylünün batıl inançlı ve kaba aklının hevesli bir dini inançla hiç aydınlatılmadığını iddia etmektedir. Sonuçta din rasyonel olarak açıklanamayan bir olgu olarak romanda yer alır. Köylülerin aradan geçen on beş sonra hala Marner 
hakkında aynı görüşte olmaları (Eliot, Silas Marner, 7), onların cehaletlerinin nasıl bir fikri sabit haline geldiğini göstermektedir.

Ebeveynleri gibi çocuklar da aynı zamanda ön yargılı ve batıl inançlıdırlar. Çocukların önyargıları iki düzeyde ortaya çıkmaktadır: Nesnelere ve insanlara karşı önyargı. Nesneler söz konusu olduğunda köyün çocukları için Silas'ın dokuma tezgahının kendisi ve sesi bir merak konusu olarak 'sorgulanabilir' (Eliot, 1996, ss. s. 4). Çünkü makine onlar için henüz çok yenidir. Bu makine onların alışık olduğu şarap makinelerinden oldukça farklı olup bundan dolayı ona şüphe ile bakarlar. Çocukların ikinci ön yargılarının konusu ise Silas Marner'a ilişkindir. Silas'ın eylemi onlara 'gizemli' görünmekte ve muhtemelen bunun şeytani olduğunu düşünüyorlar. Çocukların Silas'ı korkuyla karışık bir merak duygusuyla algılaması, 'yabancı' yı 'alaycı bir üstünlükle' görmelerine yol açar. Adeta şeytandan korkar gibi Silas'tan çekinirler. Dokumacının "korkunç bakışının arkasında, olan herhangi bir çocuğa kramp, raşitizm veya ağrılı bir dert açabileceği düşüncesi yatmaktadır" (Eliot, Silas Marner, 3-4). Silas'ta şeytani bir güç olduğu kuruntusunu taşırlar, ancak bu zararlı ve mantıksız fikirleri onlara aşlayan ebeveynlerdir. Çocukların birbirlerine Silas hakkında söyledikleri aslında ebeveynlerinden duyduklarını taklit etmektir. Buradaki anlatı, köylülerin bir şekilde Kutsal Kitap'la bağlantılı ve kaynağını oradan alan bir şeytan algısını ifade eder.

Silas Marner'ın açılışında, anlatıcı önyargı ve batıl inanç terimini kullanır, bunun çeşitli türlerini gösterir ve zararlı etkilerini sunar. İlk bölüme göre biraz daha uzun olan ikinci bölümünde, yazar, Marner'ın Raveleo'ya göç etmeden önce, yaşamını sürdürdüğü şehrin dini yapısından söz eder:

"Raveloe'ye gelmeden önceki hayatı, o günlerde olduğu gibi, o günlerde olduğu gibi, en fakirlerin yaşadığı dar bir dini tarikatta yer alan bir esnafın hayatını andıran hareket, zihinsel aktivite ve yakın arkadaşlıklarla doluydu. Burası en fakir sırdan insanın konuşma kabiliyeti ile hemen göz çarptığı, en azından, sessiz bir seçmen olarak kendi topluluğunun yönetiminde bir ağırlığa sahip olduğu bir yerdi" (Eliot, Silas Marner, 7-8). Burada dar bir dini tarikat iklimi hakim olduğu halde Silas'ı kendine çekmiştir, ancak kendisi entelektüel değil ve diğerlerinden daha iyi bir din anlayışına sahip değildir. Marner, örnek yaşamı ve ateşli inancı olan genç bir adam olduğuna inanılıyordu; kilisedeki bir ayine geç kalmış veya gelememiş olsa dahi bu durum onun üzerine odaklanan ilgiyi azaltmaya yetmiyordu (Eliot, Silas Marner, 8). Silas olmayabilir entelektüel, ama samimi ve dürüsttü. "Daha az akıllı bir insan pek fazla düşünmeden kendisine belletilen şeylere pekâlâ inanabilirdi; fakat Silas hem aklı başında hem de dürüsttü, ancak birçok dürüst ve hür insanın durumunda olduğu gibi kültür onun, içinde taşıdığı bu gizem duygusuna bir tanım getirememişti ve bu nedenle kendisini sorgulama ve bilgi yolunda doğru şekilde ilerledi" (Eliot, Silas Marner, 8). Dine inanmanın akli melekeleri ve ahlaki normları tam olarak gelişimini tamamlamamış olan insanlara yakıştırılan bir nitelik olduğundan dolayı Silas gibi zeki, dürüst bir insanın dini inançlara sahip olması bir istisna olarak görülür. Ancak o da inançlarını körü körüne savunmak yerine onları bilimsel temellere bina etmeye çalışır (Eliot, Silas Marner, s. 8). Silas Marner, kilise çevresinde de, tıpkı köylülerde olduğu gibi, sıradışı olumsuz bir izlenime sahiptir. Bunlara göre Marner, Şeytan'la ilişkili bir kişidir. Gerçekten de, belli bir güce sahipti, ama bu şeytani bir türden bir güçtür. Bu insanlardan biri olan Mr Macey'e göre Marner "Eğer isterse daha fazla insanı tedavi edebilirdi", ama "sadece onun zararından korunmak için olsa dahi konuşmaya değerdi" (Eliot, Silas Marner, s. 7). Dahası, köylüler, özellikle daha zengin olanlar, çevredeki tek dokumacı olduğu için ona ihtiyaç duyuyordu. Fakat onların da Marner hakkında ön yargılarında bir farklılık söz konusu değildir. Dolayısıyla, Kilise çevresi gibi eğitimli insanlardan, dar görüşlü köylülere ve sosyal ilişkileri gelişmiş olan zengin ve varlıklı insanlara dek hepsinin ortak özellikleri din konusundaki tutumlarının yön verdiği sı̆̆, önyargılı ve insanı düşman gören bir anlayışa sahip olmalarıdır. Dinin etkisindeki insanların bu tutumu, 
Eliot'ın çıkarsamasına göre, dinin doğasındaki yanlış anlayışların bir tezahürüdür. Bir başka açıdan, denilebilir ki, Eliot din konusundaki iddiasını kanıtlamak için buna uygun örnekleri ileri sürmektedir.

Silas Marner'ın başından geçen bir olay, onun yaşamında bir dönüm noktası olarak yerini alır. Olay arkadaşı ve dindar olarak bildiği bir insan olan William Dane'nın Kilisenin parasını çalıp suçu Marner'ın üzerine yıkmasıdır. Teoloji böylece insanlığın tıpkı Eliot'un teolojik adamı William Dane gibi, romandaki Silas'a ihanet eder. William kilisenin parasını çaldıktan sonra ve Silas'a suçu yükledikten sonra dahi Marner, arkadaşının böylesi bir davranış içinde olacağına inanmakta zorlanır. Bir an düşündükten sonra aniden zihninden bir aydınlanma belirir ve birden bire ne olduğunu anlar (Eliot, Silas Marner, s. 11). Silas cebinde bıçak olmadığını hatırlar ve William'ın ihanetini fark eder ancak sessiz kalmayı ve kendini savunmamayı yeğler zira ikisinden başka, olayı gören bilen başka bir kimse yoktur. Ayrıca kendisinin masum olduğundan son derece emin olmasına karşın Marner, yine de bir dindaşının böyle bir kötülük işleyeceğine inanmaz ve inanmak istemez hem de onu suçlamanın dini açıdan bir sakınca içerdiğini düşünür. Bu arada Silas Marner, davasında kiliseye fon sağlamak amacıyla halkın parasını çalmakla suçlanır. Fakat masumdur. Ve köyün ve Kilisenin ileri gelenleri, onun kendisini temize çıkarmasını beklerler. Suçlama ve tartışmalardan sonra Marner hala konuşmamakta direnir ve masumiyetini kanıtlamak için hiçbir şey yapmaz. Silas Marner'ın bu tutumu dinin sorgulayıcı olmayıp teslimiyetçi olduğunu düşündüren Eliot'ın anlayışını ima ettiğini akla getirmektedir. Sadece şöyle mırıldanır : "Hiçbir şey söyleyemem. Tanrı beni temize çıkaracaktır”(Eliot, Silas Marner, s. 11) Bu karar sadece kasabanın sokaklarında hüküm süren gizemli dini yaşama aşina olmayanlar için sürpriz olur. Silas, kardeşleriyle biz diz çökerek hem ilahi bir müdahale ile kendisinin masumiyetinin dile getirileceği beklentisi içinde olur. Ancak onun için artık hiçbir şey insanlara olan güveninin sarsılmasından daha üzüntü verici değildir. (Eliot, Silas Marner, s. 12). "Silas Marner'ın suçlu olduğu açıklandığında" (Eliot, Silas Marner, s. 14), Marner sadece Lantern Yard üyelerinin dini anlayışlarını reddetmekle kalmaz, dinin kendisini de hiçbir ayırım yapmadan reddeder. Her ne kadar insanların yanlış yapabileceğini, dini istismar edebileceğini düşünmesi gerektiği akla gelse de, Tanrı'dan beklediği ve derhal gerçekleşmesini beklediği şekilde masum olduğuna dair bir işaret daha doğrusu, onun istediği türden bir mucize gerçekleşmediği için dine olan inancını kaybeder. Romanda birçok kez Marner'ın yakın mesafe görüş sorunu baş gösterir. Bu durum Marner'ın sezgisel anlamda, dini yetilerin onun dar görüşlü olmasına neden olduğu şeklinde anlaşılabilir. Marner, Tanrı, insan ve din konusunda ayrım yapmamış ve bu yüzden din olduğunu düşündügü her şeye inancını yitirmiştir. Bu yüzden kaybedecek başka hiçbir şeye sahip olmadığından ve William'ın ihanetinden tamamen emin olduğundan cesurca şöyle demeye karar verdi: "En son bıçağımı kullandığımı hatırladığımda, senin için bir kayış kesmek için çıkardığım zamandı. Tekrar cebime koyduğumu hatırlamıyorum. Parayı çaldın ve günahı kapımın önüne koyacak kumpas kurdun. ” Böylece Tanrı'nın adaletini de reddeder (Eliot, 2000, s.12) Burada Marner'ın dini anlayışının da temelden yanlış olduğu ortaya çıkmaktadır. Çünkü masumiyetini kanıtlamak için kendisini savunmaması yanlış olduğu gibi adeta bir mucize beklentisi ile Tanrı'dan kendisini temize çıkarmasını istemesi de yersiz olmuştur. Ancak, eski dini geri almak isteyenlerin aksine, Eliot seküler çağdan hoşnut olan Eliot, tehlikelerinden habersizdi. Marner'ın vizyonunun sinırlarını betimleyen seküler yaşam, inancını yitirdikten sonra da bir hapishane olabilir (185). Teoloji çağı en azından bir açıdan aşkın olasılıklara izin vermiş olmasından ötürü bir seçenek oluvermiştir. Adam inancını yitirdikten sonra dünyayı dolaşan, yani kaybettikleri cennet evini arayan insanın durumuna düşmüştür. Marner, seküler dönüşüm ile iki zıt duyguyu aynı anda yaşar: Artık bir açıdan inançtan ve dinden soyutlanmış bir insan olarak içinde yaşadığı dünyada, aşkın yurtsuzluk gibi bir durumu deneyimlerken diğer taraftan kendisini bütünüyle anayurdu olarak gördüğü ve sahiplendiği bir dünyaya ait hisseder. Silas için, seküler dünya artık herhangi bir amacı olmayan bir çă̆ veya anlamsız bir dünyadır. İnancını yitirdiğinde hayat umutsuz bir bilmeceye dönüşür. Artık Tanrı'nın imgesinde yaratılmış, bir ilahın 
gözetiminde olmanın kaygısını taşıyan özel biri değil önemsiz biri olarak kendisini algılamaktadır. İlahi bir yasak yoksa, onun için hiç bir yasa yoktur. Seküler evreninde kabul ettiği tek şey şans ve kendi arzularıdır. Bunlar onun seküler inancına dönüşür. Eliot, teoloji ve sekülerizm arasında bir takım paralellikler kurar: Bunlardan her biri, diğerinin sorumluluğunu ortadan kaldırma eğiliminde olması, birisini olayların son karar vericisi olarak kabul edilen bir Tanrı'ya ve tüm insanüstü planlarının yerini aldığı düşünülen bir akla dayanma eğiliminde olmasıdır. Eliot'a göre, seküler bir bakış açısının epistemolojik bir temel olarak kabul edilmesi, ancak bir zamanlar din içerisinde yer alan idealleri reddeden materyalizmin reddedilmesini gerektirir. Modern yaşamın ihtiyaçlarına cevap verebilmek için dinin dönüştürülmesi gerekir.

\section{Sonuç}

Çağdaş edebiyatın belirleyici niteliklerinden biri haline gelen hümanizm ve sekülerizm ile din arasındaki ilişkinin niteliği ve edebiyata yansıması; pratik düzeyde edebi eserler ve özellikle romanlara konu olsa da, kuramsal düzeyde bu alanda yapılan çalışmalar sınırlıdır. Bu nedenle söz konusu çalışmada hem kuramsal düzeyde hem de uygulama düzeyinde hümanizm, din ve edebiyatın arasındaki ilişkiyi edebiyatı odak noktasına yerleştirmek suretiyle ele almaya çalıştık. Batı'da Reform ve Rönesans hareketleriyle ivme kazanan hümanizm, en önemli niteliği olan seküler yapısını, Charles Darwin’in Kitabı Mukaddes’in yaratılışa ilişkin dini açıklamalarını sarstığı eseri Türlerin Kökeni’ni yayınlamasıyla elde etti. Kitap, Hıristiyanlığın en zorlu sınamalara maruz kaldığı zaman dilimi olan geçen yüzyılda, bütün bilimlerin temellerini sarstı ve hızla diğer kültürel ve sanatsal alanlarda etkili oldu. Hümanizmin ve sekülerizmin parlak zaferi karşısında toplumsal ve kültürel hayattan soyutlanan din ancak bireysel bir ilgi konusu olmakla yetindi. Dinden boşalan toplumsal hayattaki rolünü ise hümanist seküler karakterdeki edebiyat üstlenmiş oldu. Bunun bariz sebepleri arasında edebiyatın, bireysel ve toplumsal düzlemde insan ve insana ilişkin deneyimi en iyi dile getiren bir iletişim alanı ve aynı zamanda aracı olmasıdır. Kesin değer yargıları, ilahi otoriteye dayanan referansları ile bütüncül bir dünya ve ahlak anlayışını ortaya koyan dinin aksine kuşkucu ve seküler yapısı ile Tanrı yerine insanı konumlandıran anlayışı ile hümanizm, insanı; kendi seçimlerinin bir sonucu olan dünya ile özdeş kılar. Dinin öncüllerini ise irrasyonalite olarak niteler ve reddeder. İlahi ve toplumsal olanın yerini bireyselliğin aldığı, özgürlük alanının insanın önüne yeni fırsatlar çıkardı̆̆ı hümanizm bireyin; ilk ve Ortaçağlar süresince, Kilisenin de kendisini hapseden ideolojik ve skolastik düşüncelerden kurtularak kendi aklıyla Tanrı da dahil, her türlü arayışa cevap vermek için yeteneklerini kullandığı bir zemini oluşturmaktadır. Bir başka ifadeyle hümanizm, insanın her şeyin ölçüsünün insan kabul edildiği düşüncenin ifadesidir. Hümanizmin edebiyatla ilişkisi, öncelikle edebiyatın gereksinim duyduğu malzeme olan dil ile başlar. Edebiyatın temel taşlarını oluşturan sözcükler, insana dair anlayışımızı ve dünya görüşümüze müdahale ettikleri gibi onları şekillendirmede de vazgeçilmez bir rol oynarlar. Dolayısıyla dilin kendisi, okuma edimiyle birlikte hümanizmin temel bileşenlerinden birini oluşturur. Ayrıca hümanizmin katkıda bulunduğu alanların başında gelen ve edebiyatla sıkı bir ilişkisi olan eleştiri de bu bağlamda unutulmaması gereken alanlardan biri olarak hümanizme anlamını veren unsurlardan biridir. Bireysel inanç alanına görece mesafeli olan hümanizm, kurumsal dinlere, çıkış noktası Avrupa olduğundan ötürü, özellikle bir Hristiyanlığa müdahale ederek modern bir ahlaki düzenin önünü açtı. İnsanların sosyal sorumluluğuna ve görev bilincine duyduğu inançtan ötürü hümanizm, ilahi amacın insan iradesine bağlı olarak çalışmasının ifadesi ve devamı olarak anlaşılabilir. hümanizm ve sekülerite, akıl ve insan iradesine dayanarak dine ve ilahi kaynaklı otoritelere meydan okur. Diğer taraftan Charles Taylor'a göre, Hristiyanlıktan türeyen bu hümanizm, Hristiyan destekçileri ve muhalifleri uyum içinde barındırmak için geniş bir kapsama sahiptir. Hümanizm inançta Tanrı'nın yerini insanla değişitirdiği gibi, kutsal metinler olan dinin temellerini de sanat ve edebiyat ile değiştirmiştir. Sanat ve edebiyat artık bireysel 
deneyimlerden toplumsal olana dek her türlü kültürel deneyimin formu ve içeriği haline gelmiştir. Dinin kutsal kitaplarının önemli bir bölümünü oluşturan, insanın içsel ve dünyevi, uhrevi yolculuğunda kendisine kılavuzluk etme işlevine sahip olan dini hikayeler, edebiyatın hikaye ve romanlarında insanın kişisel tecrübesine ve insanlığın ortak birikimine dönüşür. Ancak dini hikayelerdeki verili cevaplar, seküler ve hümanist edebiyatta insan aklının ve deneyiminin süzgecinden çlktıktan sonra ampirik bir bilgiye dönüşür. Çalışmamızın konusunu pratik düzeyde, roman türünde en iyi temsil ettiğini düşündüğümüz örnek eserlere yer verdik. Çalışmaya konu olan Middlemarch ve Silas Marner adlı eserlerin yazarı olan George Eliot, gerek kişisel deneyimi gerekse yazar olarak edebiyat bağlamında hümanizm, din ve sekülerizm konusunda yaptığı çalışmalarla Batı edebiyatında bu alanın önde gelen simalarından biri olmuştur. Eliot, dinin olmadığı bir dünyada seküler, hümanist bir yaşamın olanağını sorgulamış, eserlerinin temel konusu haline getirmiştir. Kişisel olarak erken yaşlarda Hristiyanlıkla yollarını ayıran Eliot, insanın ve yaşamın ilahi öğretilerden soyutlanması ile birlikte insanın karşı karşıya kaldığı durumu eserlerinde yansıtmıştır.

\section{Kaynakça}

Bonaparte, F., (1991) "Carrying the Word of the Lord to the Gentiles: Silas Marner and the Translation of Scripture into a Secular Text," Religion and Literature 23. 2, 39-60, 39.

Blackham, H. J., Hepburn, R., Martin, K., \& Nott, K. (1965). Objections to humanism.

Copson, A., \& Grayling, A. C. (Eds.). (2015). The Wiley Blackwell handbook of humanism. John Wiley \& Sons.

Dolin, T., (2005). George Eliot. Oxford: OUP.

Eliot, G., (2000). Middlemarch. Norton Critical Edition.

Eliot, G., (1996). Silas Marner. Edited by Terence Cave. Oxford: OUP.

Fanon, F., Sartre, J. P., \& Farrington, C. (1963). The wretched of the earth (Vol. 36). New York: Grove Press.

Faulkner, P. (1975). Humanism and The English Novel. Elek/Pemberton, 1975

Fowler, J. D. (1999). Humanism: Beliefs and practices. Sussex Academic Press. Hardy, T. (2017) [1922]. Late Lyrics and Earlier with many other verses. The Floating Press.

Haight, G.(ed.) (1954) The George Eliot Letters, New Haven.

Heidegger, M. (2013). Hümanizm üzerine. Ankara: Türkiye Felsefe Kurumu.

İnalcık, H. (2013). Rönesans Avrupası. İstanbul: İş Bankası Yayınları.

JanMohamed, A. R. (1984). Humanism and minority literature: Toward a definition of counterhegemonic discourse. Boundary 2, 281-299

Kierkegaard S. ( 1971) [1843]. Either/Or. (Vol. 1). Trans. David F. Swenson and Lillian Marvin Swenson. Princeton: Princeton University Press.

Lawrence, D. H., \& Lawrence, D. H. (1985). Study of Thomas Hardy and other essays (Vol. 8). Cambridge University Press.

Miller, R. B. (1981). Black American literature and humanism.

Neill, A., (2008) "The Primitive Mind of Silas Marner," ELH 75, 4, .

Nietzsche, F. (1980). Twilight of the Idols and the Anti-Christ. Translated by R. J. Hollingdale. London: Penguin Books, 1990, 80-81.

Norman, R. (2004). On Humanism. Routledge.

Orwell, G. (1957). Inside the whale and other essays. Penguin. 
Poirier, R. (1987). Modernism and its difficulties. The Renewal of Literature: Emersonian Reflections, 95-113.

Radakrishnan, R. (2007). Edward Said's literary humanism. Cultural Critique, 13-42.

Said, E. W. (2004). Humanism and democratic criticism. Columbia University Press.

Said, E. W. (2012). Culture and imperialism. Vintage.

Siddiqi, Y. (2005). Edward Said, Humanism, and Secular Criticism. Alif: Journal of Comparative Poetics, 65-88.

Svalgic, Martin J. . "Religion in the Novels of George Eliot," in A Century of George Eliot Criticism. Ed. Gordon S. Haight. Boston: Houghton Mifflin Co, 1965, 285-94, 285-86.)

Taylor, C., (2007). A Secular Age. Harvard University Press.

Thomte, R. (2009). Kierkegaard's philosophy of religion. Wipf and Stock Publishers.

Tolstoy L. (1940) [1882]. A Confession. Trans. Aylmer Maude. London:Oxford University Press.

Wallerstein, I. (1997). Eurocentrism and its avatars: The dilemmas of social science. Sociological bulletin, 46(1), 21-39.

Watt, I., (1957). The Rise of the Novel. University of California Press.

Zhang, Liang, and Lingqin Zeng (2013). "A Moral World without God-On the Religion of Humanity of George Eliot in Silas Marner." Theory \& Practice in Language Studies 3.3. 